\title{
Measuring and Leveraging Electrostatic Effects in a Charged Phos- phine
}

\author{
Andrew J. McNeece, ${ }^{\dagger}$ Margaret L. Kelty, ${ }^{\dagger}$ Alexander S. Filatov, John S. Anderson* \\ University of Chicago Department of Chemistry, 929 E 57th St., Chicago, IL, 60637 \\ Supporting Information Placeholder
}

\begin{abstract}
Local electric fields have recently been investigated for optimizing reactivity in synthetic systems. However, disentangling the relative contributions of inductive (through-bond) and electrostatic (through-space) effects in molecular systems has been a long-standing challenge. To understand the interplay of these effects and leverage electrostatic influences for enhanced reactivity, we have synthesized a distally charged phosphine, $\mathrm{Ph}_{2} \mathrm{PCH}_{2} \mathrm{BF}_{3}{ }^{-}$, and studied the effect of the charged trifluoroborate group on its donor properties and reactivity. This charged phosphine displays solvent-dependent changes in donor strength as measured by the $J_{P-S e}$ of the corresponding phosphine selenide. The variation with solvent dielectric illustrates a significant electrostatic component to the donor strength. Computations further support the importance of electrostatic contributions and highlight the effect of charge position and orientation. Finally, this charged group also greatly accelerates C-F oxidative addition reactivity in Ni complexes, experimentally verifying recent theoretical predictions. These results show that covalently bound charged functionalities can exert a significant electrostatic influence even under common solution phase reaction conditions.
\end{abstract}

\section{Introduction}

Spectroscopic and computational studies have cited oriented electric fields in active sites as key contributors to enzymatic reactivity. ${ }^{1}$ Enzymes maintain and orient electric fields using polar and charged functional groups in the protein scaffold around the active site, a strategy that is appealing for synthetic molecular systems but difficult to mimic. ${ }^{2}$ Multiple approaches have been proposed for incorporating similar electric field effects into systems that lack an enzymatic superstructure. Electric fields can be directly applied to synthetic compounds through attachment to electrode surfaces or STM tips and these approaches have been shown to increase catalytic rates. ${ }^{3}$ Another approach is to rationally append charged functional groups onto molecular scaffolds to offer control over the orientation and magnitude of electrostatic effects. Indeed, there has been enormous interest in modeling or leveraging electrostatic interactions in organic and inorganic molecules. 4,5 Computations have shown that these effects can have a large impact on reactivity and catalysis, ${ }^{6}$ such as accelerating cross coupling reactions through the lowering of barriers to oxidative addition. ${ }^{7}$

A detailed understanding of the relative impact of inductive or electrostatic effects would be valuable in tuning molecular reactivity. However, experimentally parsing out the relative inductive and electrostatic contributions to reactivity and electronic structure from charged functional groups is challenging even in simple systems. A prime example of this is in classic Hammett literature where inductive through-bond and electrostatic through-space effects for substituents were predominantly treated as one lump effect, sometimes referred to as $\sigma_{\mathrm{i} .}{ }^{8}$ However, in a subset of this literature, there has been considerable debate on whether electrostatics or through-bond electron density effects are dominant in $\sigma_{i}$. Hammett originally considered the effect of substituents to be entirely electrostatic in nature, a view supported by Ri, Eyring, and Westheimer. ${ }^{9}$ Conversely, Jaffe considered substituent effects primarily through electron density, foreshadowing modern computational analyses. ${ }^{10}$ The efficacy of both methods in rationalizing reactivity trends supports that both electrostatic and inductive contributions are active, and no simple method exists to separate these components. This historical discussion illustrates the difficulties associated with teasing apart the relative contributions between through-space and through-bond effects, and this remains an outstanding challenge. ${ }^{11}$ Nevertheless, obtaining a more detailed understanding of the relative magnitude of inductive and electrostatic effects would be valuable, particularly as leveraging through-space effects should serve as an ideal strategy to break free-energy relationships. ${ }^{12}$

Phosphines are ideal scaffolds to quantify the effect of electrostatics as there are well defined parameters and measurement techniques for the donor strength of these species such as the Tolman Electronic Parameter (TEP). ${ }^{13}$ Furthermore, charge effects with these ubiquitous ligands have recently been examined theoretically and predicted to provide enhanced metal based reactivity. ${ }^{7}$ While several anionic phosphines have been synthesized and in some cases show enhanced Suzuki- or Kumada-coupling reactivity, detailed studies aimed at understanding the relative contributions of inductive versus electrostatic effects have not been undertaken. ${ }^{14}$

We therefore targeted the anionic phosphine $\mathrm{Ph}_{2} \mathrm{PCH}_{2} \mathrm{BF}_{3}{ }^{-}$ (1) as a new scaffold to investigate the relative contributions of Scheme 1. Synthesis of K1 and reactions to form $\left[\mathrm{PPh}_{4}\right]\left[1^{\mathrm{Se}}\right], 2$, and the product of $\mathrm{C}-\mathrm{F}$ oxidative addition by a Ni complex featuring 1 .

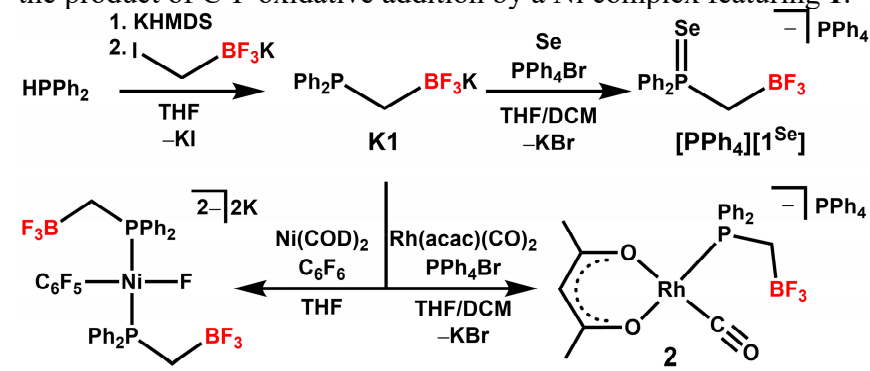



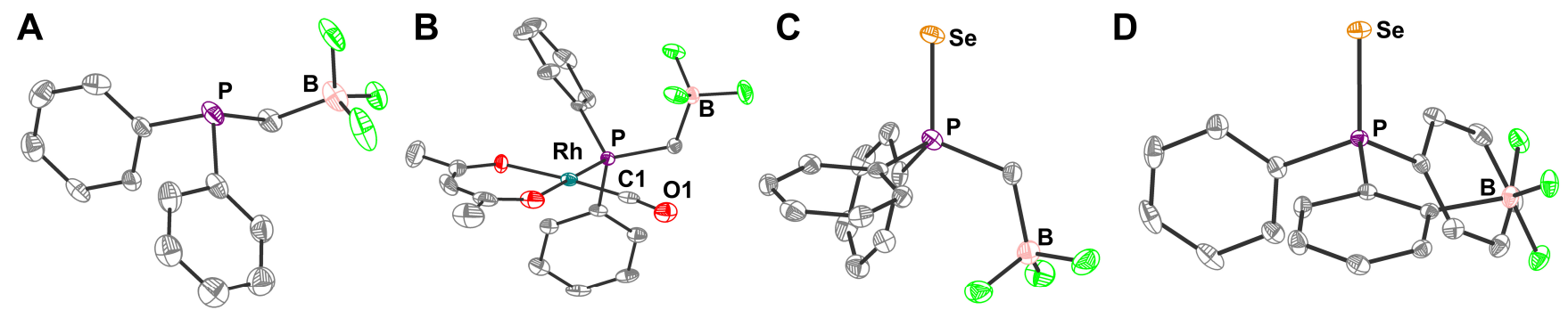

Figure 1. SXRD structures of the anions of A) K1, B) 2, C) [PPh 4$]\left[1^{\text {Se }}\right]$, and D) $\left[\mathrm{PPh}_{4}\right]\left[3^{\mathrm{Se}}\right]$ with ellipsoids at $50 \%$ and $\mathrm{H}$-atoms and counterions omitted for clarity. $\mathrm{C}$ is shown in grey, $\mathrm{O}$ in red, $\mathrm{F}$ in bright green, and other atoms types are labeled. Selected bond

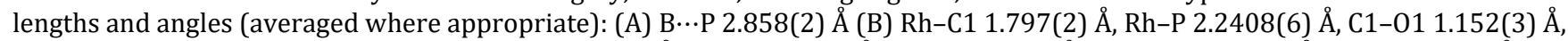

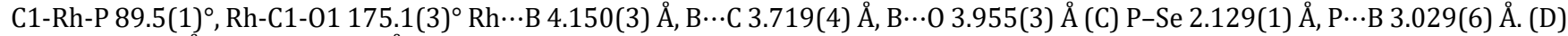
P-Se 2.112(5) Å, P...B 3.562(2) Å.

through-bond and through-space effects (Scheme 1). Here we report the synthesis of this phosphine, quantification of the electrostatic contribution to its donor properties via solvent dependent NMR coupling constants of its phosphine selenide $\mathrm{Se}=\mathrm{PPh}_{2} \mathrm{CH}_{2} \mathrm{BF}_{3}-\left(\mathbf{1}^{\mathrm{Se}}\right)$, and its complexation to $\mathrm{Rh}$ carbonyls to give $\left[\mathrm{PPh}_{4}\right]\left[\mathrm{Rh}(\mathrm{acac})(\mathrm{CO})\left(\mathrm{PPh}_{2}\left(\mathrm{CH}_{2} \mathrm{BF}_{3}\right)\right)\right](2)$. We also extend these studies to an additional anionic phosphine $\mathrm{Se}=\mathrm{PPh}_{2}(2$ $\left.\mathrm{BF}_{3} \mathrm{Ph}\right)^{-}\left(3^{\mathrm{Se}}\right)$ with a longer and more rigid aryl linker. ${ }^{14 e, \mathrm{f}}$ These studies illustrate that electrostatic interactions from charged functional groups are a major contributor to donor strength in common organic solvents. Furthermore, we demonstrate that these electrostatic interactions can be leveraged for a $\sim 600$ fold acceleration of oxidative addition reactivity, consistent with theoretical predictions.

\section{Results and Discussion}

Synthesis and Characterization $\mathrm{Ph}_{2} \mathrm{PCH}_{2} \mathrm{BF}_{3}{ }^{-}$

Synthesis of the phosphine proceeds readily via deprotonation of $\mathrm{Ph}_{2} \mathrm{PH}$ with KHMDS (KHMDS = potassium hexamethyldisilazide), followed by dropwise addition to a stirring THF solution of potassium iodomethyltrifluoroborate (Scheme 1). The reaction was monitored by ${ }^{31} \mathrm{P}\left\{{ }^{1} \mathrm{H}\right\} \mathrm{NMR}$, and growth of a quartet at -15 ppm confirmed the formation of $\mathrm{KPPh}_{2} \mathrm{CH}_{2} \mathrm{BF}_{3} \mathrm{~K}(\mathrm{~K} \mathbf{1})$ which is subsequently isolated as a white powder after workup. The ${ }^{1} \mathrm{H}$ NMR of K1 shows the expected aromatic signals for the phenyl groups, and a complicated doublet of quartets at 0.8 ppm from coupling of the $\mathrm{CH}_{2}$ linker to phosphorus, boron, and fluorine. The ${ }^{31} \mathrm{P}\left\{{ }^{1} \mathrm{H}\right\}$ NMR spectrum shows coupling to fluorine with an identical chemical shift to that observed for $\mathrm{PPh}_{2} \mathrm{Et}$. This observation is consistent with previous reports that charged phosphines have similar shifts as their neutral analogues. ${ }^{14}$ Analysis by ${ }^{19} \mathrm{~F}\left\{{ }^{1} \mathrm{H}\right\}$ and ${ }^{11} \mathrm{~B}\left\{{ }^{1} \mathrm{H}\right\}$ NMR indicated the expected shifts and coupling for a $\mathrm{R}^{-\mathrm{BF}_{3}-}$ group, supporting the presence of this anionic unit.15 Compound K1 was also structurally characterized via single-crystal X-ray diffraction (SXRD, Figure 1A). The SXRD structure shows the expected connectivity and a close association between $\mathrm{K}$ and $\mathrm{B}$ of $\sim 3 \AA$. While it is unclear if this association is preserved in solution, larger cations were chosen to limit ion pairing in further analyses (see below). The solid-state B..P distance is 2.858(2) $\AA$ which serves as a proxy for the same distance in solution.

\section{Tolman Electronic Parameter and $J_{P-S e}$ Determination}

To assay the donor strength of $\mathbf{1}$, its Tolman Electronic Parameter (TEP) was determined using a Rh carbonyl complex of the form $\mathrm{Rh}(\mathrm{acac})(\mathrm{CO}) \mathrm{L}$, a safer alternative to $\mathrm{Ni}(\mathrm{CO})_{3} \mathrm{~L}$ complexes that are classically used for this measurement. ${ }^{16}$ Addition of $\mathrm{K} 1$ to $\mathrm{Rh}(\mathrm{acac})(\mathrm{CO})_{2}$ with $\mathrm{PPh}_{4} \mathrm{Br}$ furnished [PPh 4$]\left[\mathrm{Rh}(\mathrm{acac})(\mathrm{CO})\left(\mathrm{PPh}_{2}\left(\mathrm{CH}_{2} \mathrm{BF}_{3}\right)\right)\right]$ (2) in good yield. Compound 2 was readily identified by ${ }^{31} \mathrm{P}\left\{{ }^{1} \mathrm{H}\right\}$ NMR spectroscopy from the appearance of a doublet of quartets arising from

coupling of the phosphorus nuclei to ${ }^{103} \mathrm{Rh}$ with a JP-Rh of 166 Hz. The SXRD structure of $\mathbf{2}$ shows a square planar geometry at $\mathrm{Rh}$ (Figure $1 \mathrm{~B}$ ). The $\mathrm{BF}_{3}$ unit is located significantly above the $\mathrm{Rh}$ square plane, and the $\mathrm{PPh}_{4}$ cation is not interacting with either the $\mathrm{BF}_{3}$ or the CO. Notably, the $\mathrm{B} \cdots \mathrm{C}$ and $\mathrm{B} \cdots \mathrm{O}$ distances are $3.719(4)$ and 3.955(3) A respectively, shorter than the $\mathrm{B} \cdots \mathrm{Rh}$ distance of 4.150(3) A. The solution IR spectrum of 2 in $\mathrm{CH}_{2} \mathrm{Cl}_{2}$ shows a $v_{\text {co }}$ of $1965 \mathrm{~cm}^{-1}$, which correlates to a TEP of 2061 $\mathrm{cm}^{-1}$. This TEP is very similar to that of $\mathrm{P}^{i} \mathrm{Pr}_{3}$, which has a TEP of $2059 \mathrm{~cm}^{-1}$, and is significantly more donating than would be expected for an alkyldiaryl phosphine such as $\mathrm{PPh}_{2} \mathrm{Me}$, which has a TEP of $2067 \mathrm{~cm}^{-1}$ (Figure 2).13 This result is consistent with the enhanced donation previously observed for phosphines with anionic borates. ${ }^{14}$

To further study the basicity and electron donation of $\mathbf{1}$ the corresponding phosphine selenide, $\left[\mathrm{PPh}_{4}\right]\left[\mathrm{Se}=\mathrm{PPh}_{2} \mathrm{CH}_{2} \mathrm{BF}_{3}\right]$ $\left(\left[\mathrm{PPh}_{4}\right]\left[\mathbf{1}^{\mathrm{Se}}\right]\right)$, was prepared. Phosphorus-selenium coupling constants $\left(U_{\mathrm{P}-\mathrm{Se}}\right)$ have a linear correlation with the TEP of various phosphines, providing another measure of phosphine donor strength (black squares in Figure 2). ${ }^{17}$ The relationship between $J_{\mathrm{P}-S e}$ and phosphine donor strength is best visualized by considering two limiting resonance structures for the phosphorus selenium bond, $\mathrm{Se}--\mathrm{P}+\mathrm{R}_{3}$ and $\mathrm{Se}=\mathrm{PR}_{3}$. The zwitterionic resonance structure is favored by more donating R-groups and exhibits a lower JP-Se.

In order to prepare $\left[\mathrm{PPh}_{4}\right][\mathbf{1} \mathrm{Se}], \mathrm{K} \mathbf{1}$ was stirred overnight in THF with an excess of elemental Se and $\mathrm{PPh}_{4} \mathrm{Br}$. The ${ }^{31} \mathrm{P}\left\{{ }^{1} \mathrm{H}\right\}$

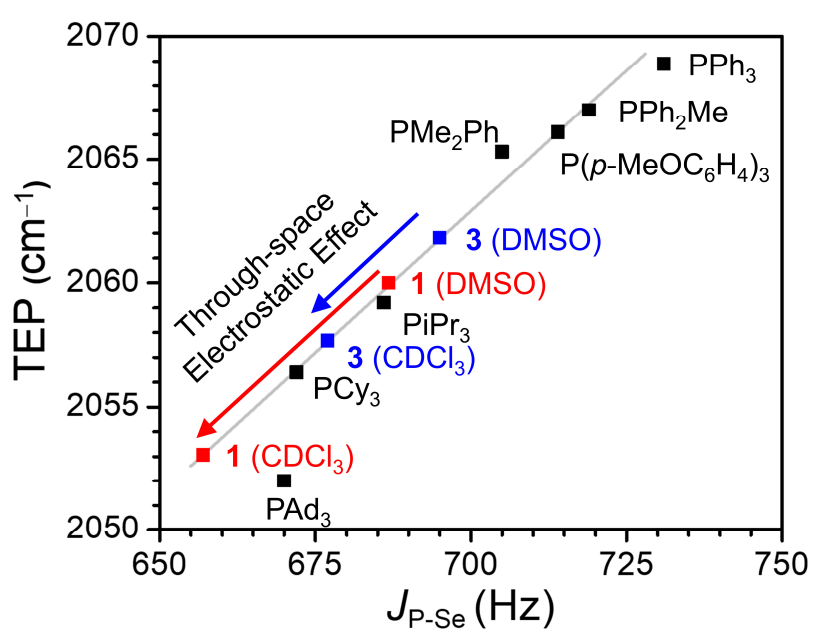

Figure 2. Correlation between the TEP of selected phosphine ligands and the JP-Se of their respective phosphine selenides (black squares, gray line is linear fit).13,17 The TEP for $\mathbf{1}$ and $\mathbf{3}$ in DMSO- $d_{6}$ and $\mathrm{CDCl}_{3}$ is extrapolated using the $J_{\mathrm{P}-\mathrm{Se}}$ of $\left[\mathrm{PPh}_{4}\right]\left[1^{\mathrm{Se}}\right]$ and $\left[\mathrm{PPh}_{4}\right]\left[3^{\mathrm{Se}}\right]$ (red and blue squares respectively). The arrows indicate the estimated electrostatic effect. 
Table 1. JP-Se Coupling Constants as a Function of Charge and Dielectric

\begin{tabular}{|c|c|c|c|c|c|c|}
\hline \multicolumn{3}{|c|}{ DFT } & \multicolumn{4}{|c|}{ Experimental } \\
\hline & $\mathrm{Se}=\mathrm{PPh}_{2} \mathrm{Et}$ & $1^{\text {Se }}$ & $\mathrm{Se}=\mathrm{PPh}_{2} \mathrm{Et}, \mathrm{CDCl}_{3}$ & 720 & $\mathrm{Se}=\mathrm{PPh}_{3}, \mathrm{CDCl}_{3}$ & 731 \\
\hline no charge & 872 & 822 & {$\left[\mathrm{PPh}_{4}\right]\left[\mathbf{1}^{\mathrm{Se}}\right], \mathrm{DMSO}-d_{6}$} & 687 & {$\left[\mathrm{PPh}_{4}\right]\left[3^{\mathrm{Se}}\right], \mathrm{DMSO}-d_{6}$} & 695 \\
\hline point charge & 819 & - & {$\left[\mathrm{PPh}_{4}\right]\left[\mathbf{1}^{\mathrm{Se}}\right], \mathrm{CDCl}_{3}$} & 657 & {$\left[\mathrm{PPh}_{4}\right]\left[\mathbf{3}^{\mathrm{Se}}\right], \mathrm{CDCl}_{3}$} & 677 \\
\hline$\Delta^{*}$ & 53 & 50 & $\begin{array}{c}\text { Overall } \Delta\left(\mathrm{Se}=\mathrm{PPh}_{2} \mathrm{Et}, \mathrm{CDCl}_{3}-\right. \\
\left.\left[\mathrm{PPh}_{4}\right]\left[\mathbf{1}^{\mathrm{Se}}\right], \mathrm{CDCl}_{3}\right)\end{array}$ & 63 & $\begin{array}{c}\text { Overall } \Delta\left(\mathrm{Se}=\mathrm{PPh}_{3}, \mathrm{CDCl}_{3}\right. \\
\left.\left[\mathrm{PPh}_{4}\right]\left[3^{\mathrm{Se}}\right], \mathrm{CDCl}_{3}\right) \\
\end{array}$ & 54 \\
\hline
\end{tabular}

All values in Hz. ${ }^{*}$ change in $\mathrm{JP}_{\mathrm{P}-\mathrm{Se}}$ compared to $\mathrm{Se}=\mathrm{PPh}_{2} \mathrm{Et}$ with no external point charge.

NMR spectrum of $\left[\mathrm{PPh}_{4}\right]\left[\mathbf{1}^{\mathrm{Se}}\right]$ contains a quartet peak at 33 ppm, with satellite quartets at 31 and $35 \mathrm{ppm}$ from coupling to the ${ }^{77}$ Se nucleus, and a singlet at 23 ppm corresponding to $\mathrm{PPh}_{4}$. The SXRD structure of $\left[\mathrm{PPh}_{4}\right]\left[\mathbf{1}^{\mathrm{Se}}\right]$ shows the $\mathrm{PPh}_{4}$ at a distance of $>6 \AA$ from $\mathrm{B}, \mathrm{P}$, or Se, which suggests little to no interaction between the charged fragments in the solid state (Figure 1C and Figure S46). In DMSO- $d_{6}$, the $J_{\mathrm{P}-\mathrm{Se}}$ of $687 \mathrm{~Hz}$ is nearly identical to the $J_{\mathrm{P}-\mathrm{Se}}$ of $\mathrm{Se}=\mathrm{P}^{i} \mathrm{Pr}_{3}$ reported in $\mathrm{CDCl}_{3 .}{ }^{17}$ The ratio between the $J_{\mathrm{P}-\mathrm{Se}}$ determined via $\left[\mathrm{PPh}_{4}\right]\left[\mathbf{1}^{\mathrm{Se}}\right]$ and the TEP determined via complex 2 fits within the established correlation (Figure 2). This JP-Se value also indicates an increase in donor strength as compared to the neutral congener $\mathrm{Se}=\mathrm{PPh}_{2} \mathrm{Et}$, which has a JP-Se of $722 \mathrm{~Hz}$ in DMSO- $d_{6} .{ }^{17}$ The TEP and JP-Se values indicate that the anionic charge promotes a large increase in the donor strength of $\left[\mathrm{PPh}_{4}\right]\left[\mathbf{1}^{\mathrm{Se}}\right]$ relative to neutral analogues, even without a conjugated linker to the phosphine. Seeing this large effect encouraged us to investigate whether there was a reasonable experimental technique to separate the through-space electrostatic component of the electron donation from the through-bond inductive effect.

\section{Analysis of Electrostatic Effects}

We predicted that the through-space electrostatic effect of the charged group could be modified or screened by the solvent environment around the molecule, while the through-bond interactions would only be slightly affected by this variable. Varying the solvent dielectric, a measure of a solvent's ability to shield a charge, 18 is therefore expected to give rise to a range of observed electrostatic effects from the same molecule simply due to differential screening. Measuring the $J$ P-Se over a range of solvent dielectrics provides a measure of this variability, as the

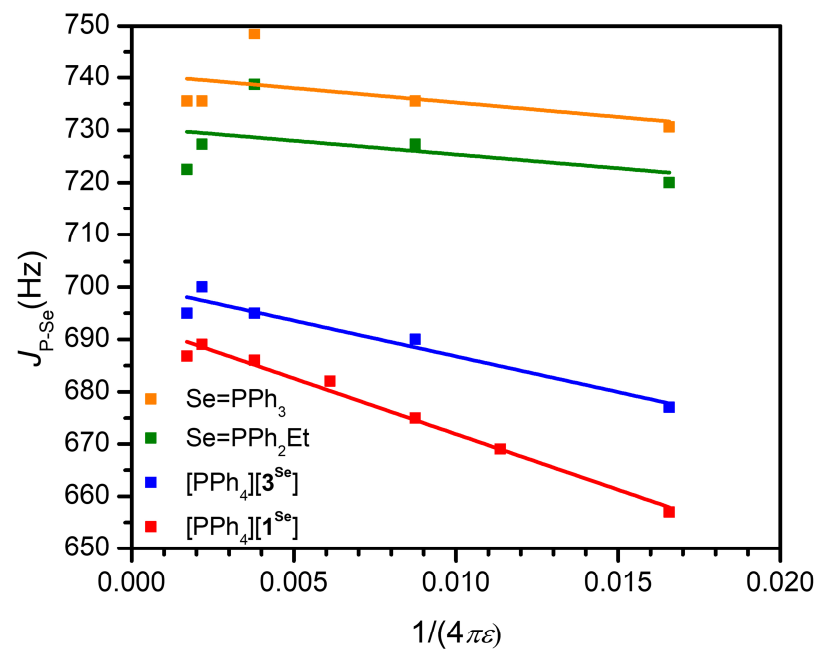

Figure 3. Solvent dependence of $J_{\mathrm{P}-\mathrm{Se}}$ for anionic and neutral phosphines. Linear fits are shown as lines. The fit data for $\left[\mathrm{PPh}_{4}\right]\left[\mathbf{1}^{\mathrm{Se}}\right]$ is provided in the text, and the fit data for $\left[\mathrm{PPh}_{4}\right]\left[3^{\mathrm{Se}}\right]$ is $\mathrm{R}^{2}=0.92$, JP-Se $=700(2)-1.4(2) * 10^{3 *}(1 /(4 \pi \varepsilon))$. Further discussion of the fits is provided in the SI. Different dielectrics $(\varepsilon)$ were generated with $\mathrm{CDCl}_{3}, \mathrm{CD}_{2} \mathrm{Cl}_{2}$, acetone- $d_{6}$, $\mathrm{CD}_{3} \mathrm{CN}$, DMSO- $d_{6}$, or mixtures thereof (see Table S5). ${ }^{20}$ zwitterionic resonance structure $\mathrm{Se}^{-}-\mathrm{P}^{+} \mathrm{R}_{3}$ should be more stabilized by an anionic $\mathrm{R}$ group in solvents with less solvent screening. This electrostatic effect would manifest as a lower $J_{\mathrm{P}}$. se in less polar solvents. It should be noted that previous literature studies demonstrate some solvent dependence to JP-Se, with one report suggesting variation between $2-3 \% .{ }^{19}$ In this analysis, comparison of $J_{\mathrm{P}-\mathrm{Se}}$ in the anionic phosphine to neutral analogues, examining the solvent dependence of these neutral analogues, and restricting the solvent choice to non-coordinating solvents help to account for any incidental trends.

The $J_{\mathrm{P}-\mathrm{Se}}$ of $\left[\mathrm{PPh}_{4}\right]\left[\mathbf{1}^{\mathrm{Se}}\right]$ was therefore measured in solvents with a range of dielectric constants to probe the relative contribution from electrostatic interactions, assuming that the through-bond interaction would be effectively constant. Coulomb's law suggests that a linear dependence on $1 /(4 \pi \varepsilon)$ would be expected for a primarily electrostatic effect. Indeed, the observed solvent dependence of $J_{\mathrm{P}-\mathrm{Se}}$ for $\left[\mathrm{PPh}_{4}\right]\left[\mathbf{1}^{\mathrm{Se}}\right]$ follows this trend; the coupling observed in DMSO- $d_{6}$ is $30 \mathrm{~Hz}$ greater than the coupling in $\mathrm{CDCl}_{3}$ (see Figure 3, Table 1, Figure S43, and Table S5). The variable solvent coupling data are well fit $\left(\mathrm{R}^{2}=\right.$ $0.98)$ to the linear relationship $J_{\mathrm{P}-\mathrm{Se}}=693(1)-$ $2.12(12) * 10^{3 *}(1 /(4 \pi \varepsilon))$. The large change in coupling as a result of variable dielectric indicates that through-space electrostatic effects are a significant contributor to the donor properties of $\mathbf{1}$. In comparison, the neutral congener $\mathrm{Se}=\mathrm{PPh}_{2} \mathrm{Et}$ is not well fit by a similar analysis and only a slight change in coupling constant across the dielectric extremes is observed, shifting from $720 \mathrm{~Hz}$ in $\mathrm{CDCl}_{3}$ to $727 \mathrm{~Hz}$ in MeCN (Figure 3, Figure S43, Table S5 and Table S6). While ion pairing should increase in low dielectric solvents and could thus impact the observed trends, the solid-state structure of $\left[\mathrm{PPh}_{4}\right]\left[\mathbf{1}^{\mathrm{Se}}\right]$ indicates there is little interaction with $\mathrm{PPh}_{4}{ }^{+}$(Figure $1 \mathrm{C}$ and Figure S46). Furthermore, control experiments with excess $\mathrm{PPh}_{4} \mathrm{Br}$ in $\mathrm{CH}_{2} \mathrm{Cl}_{2}$ showed only small changes to JP-Se $(<7 \mathrm{~Hz}$, see Figure S29).

In addition to using $J_{\mathrm{P}-\mathrm{Se}}$ to measure electrostatic contributions, we also attempted to measure these effects via IR spectroscopy. However, IR spectra of $\mathbf{2}$ and $\mathrm{Rh}(\mathrm{CO})_{2}$ (acac) in several solvents show no clear trend in $v_{\text {Co }}$ with dielectric within instrumental error (Figures S37 and S38). This is perhaps not surprising as the expected change in stretching frequency of $\sim 10 \mathrm{~cm}^{-1}$ is not large compared to the instrumental resolution $\left(4 \mathrm{~cm}^{-1}\right)$. Resolving dielectric induced shifts is further limited by spectral convolution or broadening, likely from Rh-P rotational isomers of $\mathbf{2}$ with different stretching frequencies as has been observed in other carbonyl systems. ${ }^{21}$ This manifests as substantially broader spectra for 2 versus $\mathrm{Rh}(\mathrm{CO})_{2}$ (acac). For these reasons, $J_{\mathrm{P}-\mathrm{Se}}$ serves as a better metric for examining through-space electrostatic effects in the current systems.

If we consider the $J_{\mathrm{P}-S e}$ of $\left[\mathrm{PPh}_{4}\right]\left[\mathbf{1}^{\mathrm{Se}}\right]$ in DMSO- $d_{6}$ to be indicative of the limit of no electrostatic interactions, indicating solely through-bond contributions, and the JP-Se in $\mathrm{CDCl}_{3}$ to be approaching the no-shielding limit, then we can estimate the relative magnitude of the electrostatic and through-bond interactions observed in solution measurements (Figure 2). The observed $J_{\mathrm{P}-\mathrm{Se}}$ for $\left[\mathrm{PPh}_{4}\right]\left[\mathbf{1}^{\mathrm{Se}}\right]$ in DMSO- $d_{6}$ is $687 \mathrm{~Hz}$, which is shifted by $35 \mathrm{~Hz}$ from the neutral analogue, Se=PPh $2 \mathrm{Et}(722$ 

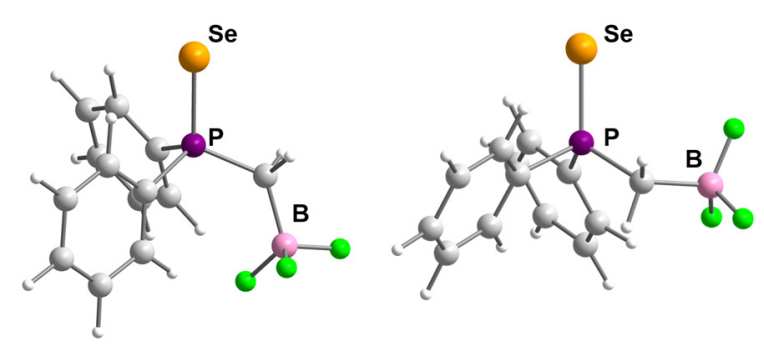

Figure 4. Calculated limiting orientations of $\mathbf{1}^{\mathrm{Se}}$, with the $\mathrm{BF}_{3}$ group close to the $\mathrm{P}=\mathrm{Se}$ axis (left, transoid) and the $\mathrm{BF}_{3}$ group far from the $\mathrm{P}=\mathrm{Se}$ axis (right, cisoid).

$\mathrm{Hz}$ ). We can therefore estimate the through-bond contribution as decreasing the $J_{\mathrm{P}-\mathrm{Se}}$ by $35 \mathrm{~Hz}$. This then indicates that the change in $J_{\mathrm{P}-S e}$ for $\left[\mathrm{PPh}_{4}\right]\left[\mathbf{1}^{\mathrm{Se}}\right]$ on moving from DMSO- $d_{6}$ to $\mathrm{CDCl}_{3}$ of $30 \mathrm{~Hz}$ is due to through-space effects, suggesting that even in the shortest case of a one-atom linker, electrostatic contributions have at least a similar effect on donor strength to throughbond interactions. Using the $y$-intercept from the linear fit to the variable solvent data, $693 \mathrm{~Hz}$, as an alternative estimate of the coupling at the high dielectric limit similarly suggests at least equal weighting for inductive and electrostatic effects.

In fact, $50 \%$ is likely a lower limit of the electrostatic contributions; while the dielectric of chloroform is small, it is still not at the vacuum limit. If we use the linear fit to the variable dielectric JP-Se for $\left[\mathrm{PPh}_{4}\right]\left[\mathbf{1}^{\mathrm{Se}}\right]$ to extrapolate what the coupling should be in the vacuum limit, we obtain a value of $524 \mathrm{~Hz}$, shifted $160 \mathrm{~Hz}$ from the DMSO- $d_{6}$ value, suggesting that the through-space electrostatic effects account for $\sim 80 \%$ of the shift in the gas-phase. In any case, this data shows that the contributions of the anionic unit to the donor properties of $\mathbf{1}$ are highly solvent dependent, and that the electrostatic component of the increase in donor strength is a major factor in common organic solvents.

\section{Computational Analysis}

To further investigate the relative contribution of throughspace versus through-bond effects, Density Functional Theory (DFT) calculations with the B3P functional were performed to estimate $J_{\mathrm{P}-\mathrm{Se}}$ and compare with experimentally determined values (Table 1). Two optimized local geometries of $\mathbf{1}^{\text {se }}$ were considered as the structure is likely fluxional during the solution NMR experiments. Both configurations have similar B $\cdots P$ distances (3.11 and $3.05 \AA$, Figure 4, left and right respectively). However, in the first geometry the $\mathrm{BF}_{3}$ is located closer to the $\mathrm{P}=\mathrm{Se}$ bond axis, with a Se-P-C-B dihedral of $158^{\circ}$ (Figure 4, left). In the second geometry, which is the minimum by 5 $\mathrm{kcal} / \mathrm{mol}$, the $\mathrm{BF}_{3}$ group is farther, with a Se-P-C-B dihedral of $74^{\circ}$ (Figure 4, right). These cisoid and transoid structures were considered as configurations of $\mathbf{1}^{\text {se }}$ that represent the limit of Se...P distances that may be present in solution, with the assumption that other configurations would be intermediate between these two. The DFT predicted JP-Se couplings emphasize that charge location matters, as the coupling calculated for the cisoid structure of $\mathbf{1}^{\text {Se }}$ was $796 \mathrm{~Hz}$ while the coupling in the transoid structure was calculated to be $849 \mathrm{~Hz}$. Taking a simple average of these two extremes gives a predicted average $J_{\mathrm{P}-\mathrm{Se}}$ of $822 \mathrm{~Hz}$. While the absolute value of this value is far from the experimentally determined one, this analysis is still useful for comparing trends with other computed scenarios. The magnitude of $J \mathrm{P}$-Se for a neutral analogue of $\mathbf{1}^{\mathrm{Se}}, \mathrm{Se}=\mathrm{PPh}_{2} \mathrm{Et}$, was calculated and found to have a value of $872 \mathrm{~Hz}$, which is $50 \mathrm{~Hz}$ higher than the average for $\mathbf{1} \mathbf{S e}$. Notably, this difference is similar to the experimentally determined difference of $63 \mathrm{~Hz}$ between $\mathrm{Se}=\mathrm{PPh}_{2} \mathrm{Et}$ and $\mathbf{1}$ se.

To explicitly analyze electrostatic effects, we used Coulomb's law to estimate the electric field at $\mathrm{P}$ in $\mathbf{1}^{\text {Se }}$ generated by a negative point charge located at the boron atom. This analysis on the two calculated structures of $\mathbf{1}^{\text {Se }}$ gives an average electric field parallel to the $\mathrm{P}=\mathrm{Se}$ bond (defined as the $\mathrm{Z}$-axis) of $\sim-0.77$ $\mathrm{V} / \AA$ (see Table S3). The magnitude of $J_{\mathrm{P}-\mathrm{Se}}$ for a neutral analogue of $1^{\mathrm{Se}}, \mathrm{Se}=\mathrm{PPh}_{2} \mathrm{Et}$, was then calculated in the presence of this same field as generated by a point charge at $\sim-4.3 \AA$ in the $\mathrm{Z}$ direction from the $\mathrm{P}$ atom. The inclusion of this point charge lowers JP-Se by $53 \mathrm{~Hz}$, to $819 \mathrm{~Hz}$. This value is similar to the difference in the calculated values between $\mathrm{Se}=\mathrm{PPh}_{2} \mathrm{Et}$ and $\mathbf{1}^{\mathrm{Se}}$, and is also nearly as large as the experimentally determined difference of $63 \mathrm{~Hz}$. A point charge is an imperfect model for inclusion of the borate group, as a point charge on the Z-axis only replicates the $\mathrm{Z}$ component of the expected field and does not include inductive effects or consider possible screening from the intervening bonds. Nevertheless, the similarity in the magnitude of the shift from adding a point charge or a borate group underscores that simply approximating the inclusion of the borate group as a predominantly electrostatic effect gives a reasonable reproduction of the calculated and experimental properties. These DFT calculations support the experimental data demonstrating that electrostatic effects play a major, and potentially dominant, role in the donor properties of $\mathbf{1}$. The computations predict that the electric field expected from a point charge, with no included inductive effects, recapitulates the DFT computed shift in $J_{P-S e}$ for $\mathbf{1}^{\text {Se }}$ versus its neutral analogue.

\section{Comparison and Extension to Other Phosphines}

Comparison of the JP-Se with other anionic phosphines is also instructive to qualitatively analyze which structural factors influence the combined through-space and through-bond effects. One relevant example is a triptycene borate phosphine that was compared to a silicon based neutral analog. ${ }^{14 \mathrm{~m}, \mathrm{n}}$ The shift in $J_{\mathrm{P}-\mathrm{Se}}$ observed in $\mathrm{CDCl}_{3}$ upon switching from the neutral to anionic version approached $90 \mathrm{~Hz}$. In the absence of data regarding the solvent dependent changes in $J_{\mathrm{P}-\mathrm{Se}}$ for this system, the shift in $\mathrm{JP}_{\mathrm{P}-\mathrm{Se}}$ in $\mathrm{CDCl}_{3}$ can be considered the combined inductive and electrostatic effect of the borate. The magnitude of the shift is larger than the $63 \mathrm{~Hz}$ shift observed between $\left[\mathrm{PPh}_{4}\right]\left[\mathbf{1}^{\mathrm{Se}}\right]$ and $\mathrm{Se}=\mathrm{PPh}_{2} \mathrm{Et}$ and can be rationalized by the orientation of the anionic functional group in each case.

In the triptycene borate the negative charge is constrained to align with the $\mathrm{P}=\mathrm{Se}$ bond, where the through-space effect on that bond would be maximized, which gives a much larger overall $J_{\mathrm{P}-\mathrm{Se}}$ change despite a P...B distance of $3.03 \AA$, which is nearly identical to that in $\left[\mathrm{PPh}_{4}\right]\left[\mathbf{1}^{\mathrm{Se}}\right]$. Additionally, the triptycene scaffold significantly precludes solvent screening directly between the borate and the $\mathrm{P}$, also likely enhancing through space interactions. The significant change in $J_{\mathrm{P}-\mathrm{Se}} \mathrm{cou}-$ pling observed in the triptycene case contrasts with another previously reported compound incorporating an anionic $\mathrm{PhBPh}_{3}$ group, $\mathrm{Se}=\mathrm{PPh}_{2}\left(p-\mathrm{BPh}_{3} \mathrm{Ph}\right)^{-} .{ }^{14 i}$ The difference in coupling between this compound and the neutral congener $\mathrm{Se}=\mathrm{PPh}_{3}$ is only $30 \mathrm{~Hz}$ in $\mathrm{CDCl}_{3}$, likely due to the larger distance between the charged group and the phosphine $(6.49 \AA$ from DFT) which attenuates the through-space effect. ${ }^{14 i}$ In addition to the lack of solvent dependent data, clear comparison of through-space effects in these previous examples is difficult due to differing through bond interactions. Multiple inductive pathways are available for the triptycene cage while a single longer pathway is available for $\mathrm{Se}=\mathrm{PPh}_{2}\left(p-\mathrm{BPh}_{3} \mathrm{Ph}\right)^{-}$. 
The selenide of a previously reported anionic phosphine that was investigated for Pd catalyzed olefin polymerization/oligomerization, $\left[\mathrm{PPh}_{4}\right]\left[\mathrm{Se}=\mathrm{PPh}_{2}\left(2-\mathrm{BF}_{3} \mathrm{Ph}\right)\right]\left(\left[\mathrm{PPh}_{4}\right]\left[3^{\mathrm{Se}}\right]\right)$, was also synthesized to test the generality of this solvent-dependence analysis, particularly in the presence of increased rigidity and possible resonance effects from an aryl linker.14e,f The SXRD structure of $\left[\mathrm{PPh}_{4}\right]\left[3^{\mathrm{Se}}\right]$ confirms the expected structure and also shows that the $\mathrm{BF}_{3}$ group is farther from the phosphine than in $\left[\mathrm{PPh}_{4}\right][1$ se] (Figure 1D, 3.562(2) and 3.029(6) $\AA$ respectively). The $\mathrm{PPh}_{4}{ }^{+}$cation is still well separated at 5.895(2) A, suggesting minimal ion pairing (see Figure S47). The solvent dependence of $J_{\mathrm{P}-\mathrm{Se}}$ for $\left[\mathrm{PPh}_{4}\right]\left[\mathbf{1}^{\mathrm{Se}}\right]$ in DMSO- $d_{6}$, $\mathrm{CD}_{3} \mathrm{CN}$, acetone- $d_{6}, \mathrm{CD}_{2} \mathrm{Cl}_{2}$, and $\mathrm{CDCl}_{3}$ was then measured. The same assumption was made that most inductive or resonance effects along the covalent linkage would be independent of solvent while electrostatic effects would be sensitive to dielectric screening.

The $J_{\mathrm{P}-\mathrm{Se}}$ of $\left[\mathrm{PPh}_{4}\right]\left[3^{\mathrm{Se}}\right]$ exhibits a solvent dependence similar to that of $\left[\mathrm{PPh}_{4}\right]\left[\mathbf{1}^{\mathrm{Se}}\right]$ (Table 1, Figure 3, Figure S43, and Table S5). The overall difference upon moving from DMSO- $d_{6}$ to $\mathrm{CDCl}_{3}$ is $18 \mathrm{~Hz}$, smaller than the $30 \mathrm{~Hz}$ shift observed for $\left[\mathrm{PPh}_{4}\right]\left[\mathbf{1}^{\mathrm{Se}}\right]$. Furthermore, the magnitude of the slope of the linear fit to the solvent dependence for $\left[\mathrm{PPh}_{4}\right]\left[3^{\mathrm{Se}}\right]$ is $\sim 70 \%$ of that for $\left[\mathrm{PPh}_{4}\right]\left[\mathbf{1}^{\mathrm{Se}}\right]$. This is consistent with the ratio predicted from a $1 /\left(r^{2}\right)$ dependence from Coulomb's law based on the relative $\mathrm{B} \cdots \mathrm{P}$ distances in $\left[\mathrm{PPh}_{4}\right]\left[3^{\mathrm{Se}}\right]$ and $\left[\mathrm{PPh}_{4}\right]\left[\mathbf{1}^{\text {Se }}\right]$ from SXRD (3.562(2) and 3.029(6) Å respectively, see SI).

The neutral congener of $\left[\mathrm{PPh}_{4}\right]\left[3^{\mathrm{Se}}\right]$, $\mathrm{Se}=\mathrm{PPh}_{3}$, was also prepared and similarly to $\mathrm{Se}=\mathrm{PPh}_{2}$ Et shows only a slight change in coupling constant with differing solvent dielectric, shifting from $730 \mathrm{~Hz}$ in $\mathrm{CDCl}_{3}$ to $735 \mathrm{~Hz}$ in DMSO- $d_{6}$ (Figure 3). The difference in $J_{\mathrm{P}-\mathrm{Se}}$ between $\mathrm{Se}=\mathrm{PPh}_{3}$ and $\left[\mathrm{PPh}_{4}\right]\left[3^{\mathrm{Se}}\right]$ in DMSO- $d_{6}$ is $40 \mathrm{~Hz}$. This effect is slightly larger than the $35 \mathrm{~Hz}$ shift observed between $\left[\mathrm{PPh}_{4}\right]\left[\mathbf{1}^{\mathrm{Se}}\right]$ and $\mathrm{Se}=\mathrm{PPh}_{2} \mathrm{Et}$ in DMSO- $d_{6}$, potentially consistent with enhanced through-bond donation in $\left[\mathrm{PPh}_{4}\right]\left[3^{\mathrm{Se}}\right]$ through the phenylene linker. Overall, the charged functional group in $\left[\mathrm{PPh}_{4}\right]\left[\mathbf{1}^{\text {Se }}\right]$ induces a larger net shift in $J_{\mathrm{P}-\mathrm{Se}}$ from the neutral analogue $(63 \mathrm{~Hz})$ than the shift induced in $\left[\mathrm{PPh}_{4}\right]\left[3^{\mathrm{Se}}\right](54 \mathrm{~Hz})$ and the experimentally determined relative through-space contribution towards donation in $\left[\mathrm{PPh}_{4}\right]\left[\mathbf{1}^{\mathrm{Se}}\right]$ is somewhat larger than that in $\left[\mathrm{PPh}_{4}\right]\left[3^{\mathrm{Se}}\right](\sim 50 \%$ and $\sim 30 \%$ respectively), consistent with a closer anionic interaction in $\left[\mathrm{PPh}_{4}\right]\left[\mathbf{1}^{\mathrm{Se}}\right]$. Similarly, using the extrapolated values from the linear fit for $\left[\mathrm{PPh}_{4}\right]\left[3^{\mathrm{Se}}\right]$ suggest an enhanced electrostatic contribution at the vacuum limit of $\sim 70 \%$, which is still slightly smaller than that predicted for $\left[\mathrm{PPh}_{4}\right]\left[\mathbf{1}^{\mathrm{Se}}\right](80 \%)$. In sum, all the experimental data acquired on both $1^{\text {se }}$ and $3^{\text {se }}$ support a significant and potentially major role that throughspace electrostatic interactions have in the donor properties of these phosphines, and furthermore illustrate that $J$ P-Se is a useful probe for deconvoluting electrostatic and inductive effects.

\section{Reactivity}

Challenging oxidative addition reactions were then targeted as a final test of the effect that negative charges have on phosphine donor properties. Phosphines placed in local electric fields generated by ionic additives have recently been calculated to lower the barriers for transition metal mediated oxidative addition of $\mathrm{C}-\mathrm{F}$ bonds which motivated the study of this reaction with $\mathrm{K1} .{ }^{7}$ Oxidative addition of hexafluorobenzene has been reported with $\mathrm{Ni}(\mathrm{COD})_{2}$ and $\mathrm{PEt}_{3}$ in hexane $(\mathrm{COD}=1,5$ cyclooctadiene), but this reaction requires four weeks to reach completion at room temperature. ${ }^{22} \mathrm{As} \mathrm{PEt}_{3}$ and $\mathrm{K} \mathbf{1}$ have similar TEP values (2061.7 and $2060 \mathrm{~cm}^{-1}$ respectively) and cone angles (132 and $140^{\circ}$ for PEt3 and $\mathrm{PPh}_{2} \mathrm{Et}$ ), this reaction was selected as a good test case to see if the anionic charge of K1 would accelerate oxidative addition as has been predicted. 27,53

Performing this reaction with K1 instead of PEt3 in THF resulted in formation of the $\mathrm{C}-\mathrm{F}$ oxidative addition product within one hour, roughly 600 times faster than with PEt3 (Scheme 1). The oxidative addition product was confirmed by characteristic ${ }^{19} \mathrm{~F}$ peaks for the $\mathrm{Ni}-\mathrm{F}$ and the $\mathrm{C}-\mathrm{F}$ ortho to the metal center as well as a single new ${ }^{31} \mathrm{P}$ peak (see Figures S2123). ${ }^{22}$ Monitoring the reaction by UV-vis spectroscopy also indicated full consumption of the starting material after one hour (see Figure S39). This reaction suggests that the electrostatic effects of the borate group are primary drivers of the enhanced reactivity and supports the growing body of research and recent theoretical predictions that electrostatic effects can be utilized to optimize reactivity or catalysis.

\section{Conclusion}

In conclusion, we have generated a new phosphine ligand and demonstrated that the inclusion of an anionic trifluoroborate group dramatically increases its donor properties relative to neutral analogues. Furthermore, through a series of experiments and calculations we have demonstrated that a significant portion of the increase in donor strength arises from electrostatic effects as opposed to inductive effects. The electrostatic interactions in this ligand enable large acceleration of oxidative addition rates in comparison to a ligand of comparable donor strength, consistent with proposals from computational investigations. While there are several examples where the effect of appended anionic groups on mono- or polydentate phosphine ligands have been explored, this work is the first case where the relative contributions from inductive versus electrostatic donation have been disentangled. The ability of charged groups to stabilize specific resonance structures, such as the zwitterionic $\mathrm{Se}^{-}-\mathrm{P}^{+} \mathrm{R}_{3}$ structure here, offers tremendous potential in tuning catalytic systems. The fact that a significant, and possibly dominant, portion of the increase in donor strength arises from electrostatic effects in common organic solvents has important implications for ligand design as the directionality of electric fields should provide a unique variable for influencing reactivity and breaking classic free-energy relationships.

\section{Experimental.}

General Considerations: All reagents were purchased from commercial suppliers and used without further purification unless otherwise specified. $\mathrm{K}\left[\mathrm{ICH}_{2} \mathrm{BF}_{3}\right], \mathrm{KPPh}_{2}\left(o-\mathrm{BF}_{3} \mathrm{Ph}\right)$, $\mathrm{Se}=\mathrm{PPh}_{3}$ and $\mathrm{Se}=\mathrm{PPh}_{2}$ Et were synthesized according to literature procedures. ${ }^{14 \mathrm{e}, \mathrm{f}, 17,23,24}$ All manipulations were carried out under an atmosphere of $\mathrm{N}_{2}$ using standard Schlenk and glovebox techniques. Glassware was dried at $180{ }^{\circ} \mathrm{C}$ for a minimum of two hours and cooled under vacuum prior to use. Solvents were dried on a solvent purification system from Pure Process Technology and stored over 4 Å molecular sieves under $\mathrm{N}_{2}$. Tetrahydrofuran was stirred over $\mathrm{NaK}$ alloy and run through an additional activated alumina plug prior to use to ensure dryness. Solvents were tested for $\mathrm{H}_{2} \mathrm{O}$ and $\mathrm{O}_{2}$ using a standard solution of sodium-benzophenone ketyl radical anion. $\mathrm{C}_{6} \mathrm{D}_{6}, \mathrm{CDCl}-$ 3 , acetone- $d_{6}, \mathrm{CD}_{3} \mathrm{CN}$, and DMSO- $d_{6}$ were dried by passage over a column of activated alumina and stored over $4 \AA$ molecular sieves in the glovebox. ${ }^{1} \mathrm{H},{ }^{13} \mathrm{C}\left\{{ }^{1} \mathrm{H}\right\},{ }^{19} \mathrm{~F}\left\{{ }^{1} \mathrm{H}\right\},{ }^{11} \mathrm{~B}\left\{{ }^{1} \mathrm{H}\right\}$, and ${ }^{31} \mathrm{P}\left\{{ }^{1} \mathrm{H}\right\}$ data were acquired on a combination of two spectrometers: a $400 \mathrm{MHz}$ Bruker DRX spectrometer equipped with a BBO probe, using Topspin 1.3; and a $500 \mathrm{MHz}$ Bruker Avance-II+ spectrometer equipped with a ${ }^{1} \mathrm{H}\left\{{ }^{19} \mathrm{~F},{ }^{13} \mathrm{C},{ }^{31} \mathrm{P}\right\}$ QNP probe, using Topspin 2.1. Chemical shifts are reported in ppm units referenced to residual solvent resonances for ${ }^{1} \mathrm{H}$ and ${ }^{13} \mathrm{C}\left\{{ }^{1} \mathrm{H}\right\}$ 
spectra, and external standards for ${ }^{31} \mathrm{P},{ }^{11} \mathrm{~B}$, and ${ }^{19} \mathrm{~F}$. NMR samples were prepared by dissolving approximately $20 \mathrm{mg}$ of the sample in about $0.5 \mathrm{~mL}$ of the appropriate deuterated solvent. No change in signal position or coupling was observed as a function of concentration. IR spectra were recorded on a Bruker Tensor II. Solution IR were recorded in a solution cell using $\mathrm{CaF}_{2}$ windows, and then the solvent signal was subtracted out. Solid IR were recorded using a $\mathrm{KBr}$ pellet. Elemental analysis was performed by Midwest Microlabs.

Synthesis of $\mathrm{Ph}_{2} \mathrm{PCH}_{2} \mathrm{BF}_{3} \mathrm{~K}$ (K1). To a stirring solution of $\mathrm{PHPh}_{2}(0.184 \mathrm{~g}, 0.99 \mathrm{mmol})$ in THF ( $\left.3 \mathrm{~mL}\right)$ was added a solution of KHMDS (0.199 g, $1 \mathrm{mmol}, 1 \mathrm{eq})$ in THF ( $3 \mathrm{~mL})$, resulting in a bright red homogeneous solution. This was added dropwise over 1 hour to a stirring slurry of $\mathrm{K}\left[\mathrm{ICH}_{2} \mathrm{BF}_{3}\right](0.285 \mathrm{~g}$, $1 \mathrm{mmol}$, $1 \mathrm{eq})$ in THF (15mL). After addition, the resulting slurry was stirred for 12 hours, filtered through Celite, and all volatiles were removed in vacuo. The resulting sticky white solid collected from drying the filtrate was washed with $\mathrm{Et}_{2} \mathrm{O}(2 \times 10$ $\mathrm{mL})$, leaving behind $\mathrm{Ph}_{2} \mathrm{PCH}_{2} \mathrm{BF}_{3} \mathrm{~K}$ as a white powder $(0.205 \mathrm{~g}$, $0.68 \mathrm{mmol}, 68 \%) .{ }^{1} \mathrm{H}$ NMR $\left(400 \mathrm{MHz}, 25{ }^{\circ} \mathrm{C}\right.$, DMSO- $\left.d_{6}\right) \delta=7.33$ $(\mathrm{t}, J=8 \mathrm{~Hz}, 4 \mathrm{H}, o-\mathrm{Ph}-\mathrm{H}), 7.24-7.17(\mathrm{~m}, 6 \mathrm{H}, m-$ and $p-\mathrm{Ph}-\mathrm{H}), 0.8$ $\left(\mathrm{dq}, J_{\mathrm{P}-\mathrm{H}}=14 \mathrm{~Hz}, J_{\mathrm{F}-\mathrm{H}}=4 \mathrm{~Hz}, 2 \mathrm{H}, \mathrm{CH}_{2}\right) .{ }^{31} \mathrm{P}\left\{{ }^{1} \mathrm{H}\right\} \mathrm{NMR}(162 \mathrm{MHz}$, $25{ }^{\circ} \mathrm{C}$, DMSO- $\left.d_{6}\right) \delta=-15.9\left(\mathrm{q}, J_{\mathrm{P}-\mathrm{F}}=13 \mathrm{~Hz}\right) .{ }^{19} \mathrm{~F}\left\{{ }^{1} \mathrm{H}\right\}$ NMR $\delta=$ $-133.5(\mathrm{~d}, 3 \mathrm{~F}, J=13 \mathrm{~Hz}) .{ }^{13} \mathrm{C}\left\{{ }^{1} \mathrm{H}\right\}$ NMR $\left(126 \mathrm{MHz}, 25^{\circ} \mathrm{C}\right.$, DMSO$\left.d_{6}\right) \delta=144.4\left(\mathrm{~d}, J_{\mathrm{C}-\mathrm{P}}=25 \mathrm{~Hz}, o-\mathrm{Ph}\right), 132.0$ (d, JC-P $=50 \mathrm{~Hz}$, ipso$\mathrm{Ph}), 127.6$ (s, $m-\mathrm{Ph}), 126.9(\mathrm{~s}, p-\mathrm{Ph}), 17.0 p-\mathrm{Ph}), 127.5\left(\mathrm{~d}, J_{\mathrm{C}-\mathrm{P}}=\right.$ $25.2 \mathrm{~Hz}, o-\mathrm{Ph}$ ), 117.5 (d, JC-P =113.4 Hz, ipso-Ph PPh4), 17.0 (broad s, $\left.\mathrm{CH}_{2} \mathrm{BF}_{3}\right) .{ }^{11} \mathrm{~B}\left\{{ }^{1} \mathrm{H}\right\}$ NMR $\left(128 \mathrm{MHz}, 25^{\circ} \mathrm{C}, \mathrm{DMSO}-d_{6}\right) \delta=$ 4.0 (broad s). IR (KBr pellet): 3419 (w), 3053 (m), $2916(\mathrm{w})$, 2885 (w), 1954 (w), 1881 (w), 1807 (w), 1584 (m), 1480 (m), 1433 (s), 1386 (m), 1168 (s), 1093 (m), 1046 (s), 931 (s), 742 (s), 697 (s). K1 was too air sensitive for reliable elemental analysis, and instead gave EA consistent with full oxidation of the phosphine sample. Elem. Anal: Calc'd $\left(\mathrm{Ph}_{2} \mathrm{PCH}_{2} \mathrm{BF}_{3} \mathrm{~K}+\mathrm{O}\right)$ : $\mathrm{C} 48.5$ H 3.8 N 0 Found: C 48.1 H 4.0 N 0.

Synthesis of $\left[\mathrm{PPh}_{4}\right]\left[\mathrm{Rh}(\mathrm{acac})(\mathrm{CO})\left(\mathrm{PPh}_{2}\left(\mathrm{CH}_{2} \mathrm{BF}_{3}\right)\right)\right]$ (2). To a stirring THF solution $(3 \mathrm{~mL})$ of $\mathrm{Rh}(\mathrm{acac})(\mathrm{CO})_{2}(0.067 \mathrm{~g}$. $0.26 \mathrm{mmol})$ was added a THF solution $(5 \mathrm{~mL})$ of $\mathrm{K} 1(0.080 \mathrm{~g}$, $0.26 \mathrm{mmol}, 1 \mathrm{eq})$ and a DCM solution ( $4 \mathrm{~mL})$ of $\mathrm{PPh}_{4} \mathrm{Br}(0.115$ $\mathrm{g}, 0.26 \mathrm{mmol}, 1 \mathrm{eq}$ ), resulting in a color change from light yellow to brown. The reaction was stirred at room temperature for 1 hour, then filtered, evacuated to dryness, and washed with petroleum ether leaving $\left[\mathrm{PPh}_{4}\right]\left[\mathrm{Rh}\right.$ (acac) $\left.(\mathrm{CO})\left(\mathrm{PPh}_{2}\left(\mathrm{CH}_{2} \mathrm{BF}_{3}\right)\right)\right]$ as a brown oil, which was crystallized by vapor diffusion of $\mathrm{Et}_{2} \mathrm{O}$ into a $\mathrm{CHCl}_{3}$ or $\mathrm{DCM}$ solution at room temperature. ${ }^{1} \mathrm{H}$ NMR (400 MHz, $\left.25^{\circ} \mathrm{C}, \mathrm{CDCl}_{3}\right) \delta=7.85(\mathrm{~m}, 8 \mathrm{H}, \mathrm{Ph}) 7.73(\mathrm{~m}, 16 \mathrm{H}, \mathrm{Ph})$, $7.57(\mathrm{~m}, 6 \mathrm{H}, \mathrm{Ph}) 7.19(\mathrm{~m}, 6 \mathrm{H}, \mathrm{Ph}) 5.30(\mathrm{~s}, 1 \mathrm{H}, \mathrm{acac}), 1.92$ (s, 3H, acac), $1.62\left(\mathrm{~m}, 2 \mathrm{H}, \mathrm{CH}_{2}-\mathrm{BF}_{3}\right), 1.56(\mathrm{~s}, 3 \mathrm{H}, \mathrm{acac}) .{ }^{31} \mathrm{P}\left\{{ }^{1} \mathrm{H}\right\} \mathrm{NMR}$ $\left(162 \mathrm{MHz}, 25^{\circ} \mathrm{C}, \mathrm{CDCl}_{3}\right) \delta=40.35\left(\mathrm{dq}, J_{\mathrm{Rh}}=166 \mathrm{~Hz}, J_{\mathrm{P}-\mathrm{F}}=10 \mathrm{~Hz}\right.$, $\left.1 \mathrm{P}, \mathrm{PPh}_{2}\left(\mathrm{CH}_{2} \mathrm{BF}_{3}\right)\right), 25.58\left(\mathrm{~s}, 1 \mathrm{P}, \mathrm{PPh}_{4}\right) .{ }^{19} \mathrm{~F}\left\{{ }^{1} \mathrm{H}\right\} \mathrm{NMR}(162 \mathrm{MHz}$, $\left.25{ }^{\circ} \mathrm{C}, \mathrm{CDCl}_{3}\right) \delta=-131.59$ (broad s, 3F, BF $) .{ }^{13} \mathrm{C}\left\{{ }^{1} \mathrm{H}\right\}$ NMR $(126$ $\mathrm{MHz}, 25^{\circ} \mathrm{C}, \mathrm{CDCl}_{3}$ ) $\delta=185.47$ (s, acac CO, 135.68 (d, Jc-P $=2 \mathrm{~Hz}$, $p$-Ph) 134.43 (d, $J_{\mathrm{C}-\mathrm{P}}=13 \mathrm{~Hz}, m-\mathrm{Ph}$ ) , 133.82 (d, $J_{\mathrm{C}-\mathrm{P}}=13 \mathrm{~Hz}, m-$ $\mathrm{Ph}$ ), 130.77 (d, $\left.J_{\mathrm{C}-\mathrm{P}}=16 \mathrm{~Hz}, m-\mathrm{Ph} \mathrm{PPh}_{4}\right) 128.31$ (s, acac COCCO) 126.92 (d, Jc-P $=13 \mathrm{~Hz}, m-\mathrm{Ph}) 117.53$ (d, JC-P $=112 \mathrm{~Hz}$, ipso-Ph, $\left.\mathrm{PPh}_{4}\right), 26.85\left(\mathrm{~s}\right.$, acac $\left.\mathrm{CH}_{3}\right) .{ }^{11} \mathrm{~B}\left\{{ }^{1} \mathrm{H}\right\} \mathrm{NMR}\left(128 \mathrm{MHz}, 25^{\circ} \mathrm{C}, \mathrm{CDCl}_{3}\right)$ $\delta=3.4$ (broad s). IR (DCM solution, $\mathrm{CaF}_{2}$ windows, $\mathrm{cm}^{-1}$ ): 3068

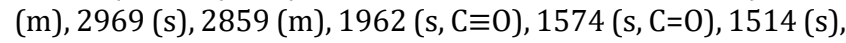
1487 (m), 1434 (m), 1383 (m), 1167 (m), 1104 (s). Elem. Anal: Calc'd ([PPh4 $\left.]\left[\mathrm{Rh}(\mathrm{acac})(\mathrm{CO})\left(\mathrm{PPh}_{2}\left(\mathrm{CH}_{2} \mathrm{BF}_{3}\right)\right)\right]\right)$ C $61.8 \mathrm{H} 4.7 \mathrm{~N} 0$. Found: C $61.5 \mathrm{H} 4.9 \mathrm{~N} 0$.

Synthesis of $\left[\mathrm{PPh}_{4}\right]\left[\mathrm{Se}=\mathrm{PPh}_{2}\left(\mathrm{CH}_{2} \mathrm{BF}_{3}\right)\right]\left(\left[\mathrm{PPh}_{4}\right]\left[\mathbf{1}^{\mathrm{Se}}\right]\right)$. To a stirring solution of $\mathbf{1}(0.050 \mathrm{~g}, 0.016 \mathrm{mmol})$ in THF $(10 \mathrm{~mL})$ was added a 10 -fold excess of solid selenium powder $(0.124 \mathrm{~g}, 0.16$ mmol, 10 eq), followed by $\mathrm{PPh}_{4} \mathrm{Br}(0.075 \mathrm{~g}, 0.017 \mathrm{mmol}, 1.05$ eq) in DCM (5 mL). This mixture was stirred overnight, then filtered through Celite and all volatiles were removed in vacuo. Crystallization by vapor diffusion of $\mathrm{Et}_{2} \mathrm{O}$ into a $\mathrm{CDCl}_{3}$ or $\mathrm{DCM}$ solution of $\left[\mathrm{PPh}_{4}\right]\left[\mathbf{1}^{\mathrm{Se}}\right]$ gave the product as clear crystals $(0.060$ g, $0.085 \mathrm{mmol}, 53 \%$ ). The sample for elemental analysis was crystallized from a mixture of hot MeCN and THF. ${ }^{1} \mathrm{H}$ NMR (400 $\left.\mathrm{MHz}, 25^{\circ} \mathrm{C}, \mathrm{CDCl}_{3}\right) \delta=8.01-7.95(\mathrm{~m}, 4 \mathrm{H}, o-\mathrm{Ph}-\mathrm{H}), 7.91-7.86(\mathrm{~m}$, $\left.4 \mathrm{H}, \mathrm{PPh}_{4}\right), 7.78-7.73\left(\mathrm{~m}, 8 \mathrm{H}, \mathrm{PPh}_{4}\right), 7.65-7.60$ (m, 8H, $\left.\mathrm{PPh}_{4}\right)$, 7.31-7.20 (m, 6H, $m$ - and $p-\mathrm{Ph}-\mathrm{H}) 1.94\left(\mathrm{dq}, J_{\mathrm{P}-\mathrm{H}}=10 \mathrm{~Hz}, J_{\mathrm{F}-\mathrm{H}}=4\right.$ $\left.\mathrm{Hz}, 2 \mathrm{H}, \mathrm{CH}_{2} \mathrm{BF}_{3}\right) .{ }^{31} \mathrm{P}\left\{{ }^{1} \mathrm{H}\right\} \mathrm{NMR}\left(162 \mathrm{MHz}, 25^{\circ} \mathrm{C}, \mathrm{CDCl}_{3}\right) \delta=33.59$ (q, JP-F $\left.=10 \mathrm{~Hz}, J_{\mathrm{P}-\mathrm{Se}}=656 \mathrm{~Hz}, 1 \mathrm{P}, \mathrm{Se}=\mathrm{PPh}_{2}\left(\mathrm{CH}_{2} \mathrm{BF}_{3}\right)\right), 22.08(\mathrm{~s}$, 1P, $\left.\mathrm{PPh}_{4}\right) \cdot{ }^{19} \mathrm{~F}\left\{{ }^{1} \mathrm{H}\right\}$ NMR $\left(162 \mathrm{MHz}, 25^{\circ} \mathrm{C}, \mathrm{CDCl}_{3}\right) \delta=-132.93(\mathrm{~d}$, $J \mathrm{P}-\mathrm{F}=10 \mathrm{~Hz}) \cdot{ }^{13} \mathrm{C}\left\{{ }^{1} \mathrm{H}\right\} \mathrm{NMR}\left(126 \mathrm{MHz}, 25^{\circ} \mathrm{C}, \mathrm{CDCl}_{3}\right) \delta=135.9(\mathrm{~d}$,

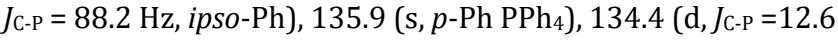
$\mathrm{Hz}, m-\mathrm{Ph} \mathrm{PPh}_{4}$ ), 132.3 (d, JC-P $=12.6 \mathrm{~Hz}, m-\mathrm{Ph}$ ), 130.9 (d, $J_{\mathrm{C}-\mathrm{P}}$ $=25.2 \mathrm{~Hz}, o-\mathrm{Ph} \mathrm{PPh}$ ), $129.8(\mathrm{~s}, p-\mathrm{Ph}), 127.5\left(\mathrm{~d}, J_{\mathrm{C}-\mathrm{P}}=25.2 \mathrm{~Hz}, o-\right.$ $\mathrm{Ph}), 117.5\left(\mathrm{~d}, J_{\mathrm{C}-\mathrm{P}}=113.4 \mathrm{~Hz}\right.$, ipso-Ph $\left.\mathrm{PPh}_{4}\right), 26.7$ (broad s, $\left.\mathrm{CH}_{2} \mathrm{BF}_{3}\right) .{ }^{11} \mathrm{~B}\left\{{ }^{1} \mathrm{H}\right\}$ NMR $\left(128 \mathrm{MHz}, 25^{\circ} \mathrm{C}, \mathrm{CDCl}_{3}\right) \delta=3.0$ (broad s). IR (CDCl 3 solution): $3058(\mathrm{~m}), 1978(\mathrm{w}), 1907(\mathrm{w}), 1814(\mathrm{w})$, 1590 (m), 1487 (m), 1438 (s), 1310 (w), 1144 (m), 1103 (s), 1023 (s). Elem. Anal: Calc'd ([PPh $]$ [Se $\left.=\mathrm{PPh}_{2}\left(\mathrm{CH}_{2} \mathrm{BF}_{3}\right)\right] \mathrm{C} 64.8 \mathrm{H}$ 4.7 N 0. Found: C 65.0 H 4.7 N 0.3.

Synthesis of $\left[\mathrm{PPh}_{4}\right]\left[\mathrm{Se}=\mathrm{PPh}_{2}\left(2-\mathrm{BF}_{3} \mathrm{Ph}\right)\right]\left(\left[\mathrm{PPh}_{4}\right]\left[3^{\mathrm{Se}}\right]\right)$. To a stirring acetonitrile solution $(10 \mathrm{~mL})$ of $\mathrm{K}\left[\mathrm{PPh}_{2}\left(2-\mathrm{BF}_{3} \mathrm{Ph}\right)\right]$ $(0.050 \mathrm{~g}, 0.14 \mathrm{mmol})$ was added an excess of elemental selenium (0.109 g, $1.4 \mathrm{mmol}, 10 \mathrm{eq})$ and this mixture was stirred for 6 hours at room temperature. The solution was filtered, and $\mathrm{PPh}_{4} \mathrm{Br}(0.062 \mathrm{~g}, 0.14 \mathrm{mmol}, 1 \mathrm{eq})$ was added as a solid, the resulting slurry was stirred for $10 \mathrm{~min}$, then all volatiles were removed under vacuum. The white powder was washed with 2 mL $\mathrm{CHCl}_{3}$ to remove excess $\mathrm{PPh}_{4} \mathrm{Br}$, and then extracted into $\mathrm{MeCN}$. Crystallization by diffusion of $\mathrm{Et}_{2} \mathrm{O}$ into the filtered MeCN solution afforded $\left[\mathrm{PPh}_{4}\right]\left[\mathrm{Se}=\mathrm{PPh}_{2}\left(2-\mathrm{BF}_{3} \mathrm{Ph}\right)\right]$ as clear crystals (Yield: $0.010 \mathrm{~g}, 0.014 \mathrm{mmol}, 10 \%) .{ }^{1} \mathrm{H}$ NMR $(400 \mathrm{MHz}$, $\left.25{ }^{\circ} \mathrm{C}, \mathrm{CD}_{3} \mathrm{CN}\right) \delta=8.04\left(\mathrm{dd}, 1 \mathrm{H}, J_{\mathrm{F}-\mathrm{H}}=16 \mathrm{~Hz}, J_{\mathrm{H}-\mathrm{H}}=8 \mathrm{~Hz}\right) 7.91(\mathrm{t}$, $4 \mathrm{H}, J=8 \mathrm{~Hz}), 7.76-7.65(\mathrm{~m}, 20 \mathrm{H}), 7.4-7.2(\mathrm{~m}, 9 \mathrm{H}) .{ }^{31} \mathrm{P}\left\{{ }^{1} \mathrm{H}\right\} \mathrm{NMR}$ $\left(162 \mathrm{MHz}, 25^{\circ} \mathrm{C}, \mathrm{CD}_{3} \mathrm{CN}\right) \delta=40.3\left(\mathrm{~s}, J_{\mathrm{P}-\mathrm{Se}}=700 \mathrm{~Hz}, 1 \mathrm{P}, \mathrm{P}=\mathrm{Se}\right)$, 22.9 (s, 1P, PPh 4$) .{ }^{19} \mathrm{~F}\left\{{ }^{1} \mathrm{H}\right\} \operatorname{NMR}\left(162 \mathrm{MHz}, 25^{\circ} \mathrm{C}, \mathrm{CD}_{3} \mathrm{CN}\right) \delta=$ $-132.6\left(\mathrm{~m}, 3 \mathrm{~F}, \mathrm{BF}_{3}\right) .{ }^{13} \mathrm{C}\{1 \mathrm{H}\} \mathrm{NMR}\left(126 \mathrm{MHz}, 25^{\circ} \mathrm{C}, \mathrm{CD}_{3} \mathrm{CN}\right) \delta=$ 136.9 (d, JC-P $=97 \mathrm{~Hz}$, ipso-Ph), 136.4 (s, p-Ph $\mathrm{PPh}_{4}$ ), 135.9 (s), 135.8 (d, JC-P $=16 \mathrm{~Hz}, C^{3}-\mathrm{Ar}$ ), 135.7 (d, JC-P $=13 \mathrm{~Hz}, m-\mathrm{Ph} \mathrm{PPh}_{4}$ ), 133.4 (d, JC-P $=13 \mathrm{~Hz}, m-\mathrm{Ph}), 132.0$ (s), 131.3 (d, $J_{\mathrm{C}-\mathrm{P}}=13 \mathrm{~Hz}, o^{-}$ $\mathrm{Ph} \mathrm{PPh}_{4}$ ), 130.9 (s, $\left.p-\mathrm{Ph}\right), 128.3$ (d, $\left.J_{\mathrm{C}-\mathrm{P}}=13 \mathrm{~Hz}, o-\mathrm{Ph}\right), 126.4$ (d, $\left.J_{\mathrm{C}-\mathrm{P}}=25 \mathrm{~Hz}, C^{6}-\mathrm{Ar}\right), 119.0\left(\mathrm{~d}, J_{\mathrm{C}-\mathrm{P}}=113 \mathrm{~Hz}\right.$, ipso-Ph PPh 4$) .{ }^{11} \mathrm{~B}\left\{{ }^{1} \mathrm{H}\right\}$ $\operatorname{NMR}\left(128 \mathrm{MHz}, 25^{\circ} \mathrm{C}, \mathrm{CDCl}_{3}\right) \delta=2.4$ (broad q, JB-F $\left.=51 \mathrm{~Hz}\right)$. IR (KBr pellet): 3048 (m) 1586 (m) 1482 (m) 1434 (s) 1315 (w) 1260 (w) 1181 (m) 1162 (m) 1109 (s) 1052 (w) 978 (m) 955 (m) 935 (s) 759 (m) 725 (s) 691 (s) 610 (m). Elem. Anal: Calc'd $\left(\left[\mathrm{PPh}_{4}\right]\left[\mathrm{Se}=\mathrm{PPh}_{2}\left(2-\mathrm{BF}_{3} \mathrm{Ph}\right)\right]\right) \mathrm{C} 67.5 \mathrm{H} 4.6 \mathrm{~N} \mathrm{0.} \mathrm{Found:} \mathrm{C} 67.7 \mathrm{H}$ $4.9 \mathrm{~N} 0$.

Oxidative Addition Reaction with $\mathbf{C}_{6} \mathbf{F}_{6}$. To a stirring THF slurry (1 mL) of $\mathrm{Ni}(\mathrm{COD}) 2(0.014 \mathrm{~g}, 0.051 \mathrm{mmol})$ was added a THF solution ( $1 \mathrm{~mL}$ ) of K1 ( $0.030 \mathrm{~g}, 0.099 \mathrm{mmol}, 1.9 \mathrm{eq})$ and an excess of $\mathrm{C}_{6} \mathrm{~F}_{6}(0.20 \mathrm{~g}, 1.07 \mathrm{mmol}, 21 \mathrm{eq})$, resulting in a deep red solution. After stirring for one hour, the solution had become brown-yellow, and NMR indicated oxidative addition of the C$\mathrm{F}$ bond via the appearance of characteristic ${ }^{19} \mathrm{~F}$ NMR peaks at $-383(\mathrm{Ni}-\mathrm{F})$ and $-117(\mathrm{o}-\mathrm{C}-\mathrm{F}) \mathrm{ppm}$ and the disappearance of 31P peaks associated with K1 (see Figures S21-23). Further characterization of the oxidative addition product could not be obtained due to the instability of the resulting species. Tracking by UV-visible spectroscopy indicated consumption of the starting material after 1 hour (see Figure S39). Reactions using $\mathrm{PEt}_{3}$ under identical conditions resulted in no reaction after one 
hour and only partial reaction after one week (see Figure S24), consistent with previous literature reports. ${ }^{22}$

$\mathrm{X}$-ray Structure Determination. The diffraction data were measured at $100 \mathrm{~K}$ on a Bruker D8 VENTURE with PHOTON 100 CMOS detector system equipped with a Mo-target microfocus X-ray tube $(\lambda=0.71073 \AA)$. Data reduction and integration were performed with the Bruker APEX3 software package (Bruker AXS, version 2015.5-2, 2015). Data were scaled and corrected for absorption effects using the multi-scan procedure as implemented in SADABS (Bruker AXS, version 2014/5, 2015, part of Bruker APEX3 software package). The structure was solved by the dual method implemented in SHELXT25 and refned by a full-matrix least-squares procedure using OLEX2326 software package (XL refinement program version 2014/727). Suitable crystals were mounted on a cryo-loop and transferred into the cold nitrogen stream of the Bruker D8 Venture diffractometer. Most of the hydrogen atoms were generated by geometrical considerations and constrained to idealized geometries and allowed to ride on their carrier atoms with an isotropic displacement parameter related to the equivalent displacement parameter of their carrier atoms. The co-crystallized THF and phenyl rings of the phosphine were modeled for disorder in $\mathrm{K} \mathbf{1}$. For [ $\left.\mathrm{PPh}_{4}\right]\left[\mathbf{1}^{\mathrm{Se}}\right]$, after fully solving and refining the structure, relatively large residual peak was observed suggesting a possible co-crystallized submixture. The peak was located close to the $\mathrm{CH}_{2}-\mathrm{BF}_{3}$ bond, and the distance correlated well with a P-I bond length. Thus, this component was refined as a $\left(\mathrm{Ph}_{2}\right) \mathrm{P}-\mathrm{I}$ (refined occupancy about $\left.4 \%\right)$. While it is hard to concretely assign the identity of such a small submixture, we note that several examples of $\left(\mathrm{R}_{2}\right) \mathrm{P}$-I molecules have been previously reported with P-I bond lengths between $2.45-2.55 \AA$ ) ${ }^{28}$ Computational Details. The structures of $1^{\mathrm{Se}}$ and $\mathrm{Se}=\mathrm{PPh}_{2} \mathrm{Et}$ were optimized in Orca version $4.0^{29}$ using the B3P functional with the def2-TZVP basis set on C,H,B, and F, and def2-TZVPP basis set on Se and P. NMR couplings were calculated in on the optimized structures using Gaussian $16^{30}$ with the "Mixed" method using mPW1PW91 functional and 6-311G(2d,2p) basis set, similar to methods used in the literature to calculate Se chemical shifts. ${ }^{31}$ Different local minima geometries of the $\mathrm{BF}_{3}$ group were found by changing the input geometry, which allowed optimization to local minima in the two extremes of the $\mathrm{BF}_{3}$ positioning.

\section{ASSOCIATED CONTENT}

\section{Supporting Information}

The Supporting Information is available free of charge on the ACS Publications website.

NMR, IR, and UV-visible spectra, and computational and crystallographic details (PDF)

\section{AUTHOR INFORMATION}

\section{*Corresponding Author}

jand312@uchicago.edu

\section{Notes}

†These authors contributed equally.

The authors declare no competing financial interests.

\section{ACKNOWLEDGMENT}

This work was supported by the National Institutes of Health (R35 GM133470). M. L. K. was supported by the NSF Graduate Student Fellowship Grant No. DGE-1144082 and DGE1746045. We thank the University of Chicago for funding as well as 3M corporation for a NTFA and the Sloan Foundation for a Research Fellowship to J.S.A. (FG-2019-11497). We also thank the Research Computing Center at the University of Chicago for providing computing resources. We thank Dr. Josh Kurutz for his helpful discussion and assistance with NMR spectroscopy and Joseph Schneider for helpful discussions.

\section{REFERENCES}

[1] (a) Warshel, A., Electrostatic origin of the catalytic power of enzymes and the role of preorganized active sites.J. Biol. Chem. 1998, 273 (42), 27035-27038. (b) Warshel, A.; Sharma, P. K.; Kato, M.; Xiang, Y.; Liu, H.; Olsson, M. H. M., Electrostatic basis for enzyme catalysis. Chem. Rev. 2006, 106 (8), 3210-3235. (c) Schyman, P.; Lai, W.; Chen, H.; Wang, Y.; Shaik, S., The Directive of the Protein: How Does Cytochrome P450 Select the Mechanism of Dopamine Formation? J. Am. Chem. Soc. 2011, 133 (20), 7977-7984. (d) Fried, S. D.; Boxer, S. G., Measuring Electric Fields and Noncovalent Interactions Using the Vibrational Stark Effect. Acc. Chem. Res. 2015, 48 (4), 998-1006. (e) Fried, S. D.; Boxer, S. G., Electric Fields and Enzyme Catalysis. Annu. Rev. Biochem. 2017, 86, 387-415. (f) Morgenstern, A.; Jaszai, M.; Eberhart, M. E.; Alexandrova, A. N. Quantified Electrostatic Preorganization in Enzymes Using the Geometry of the Electron Charge Density Chem. Sci. 2017, 8, 5010-5018.

[2] (a) Shaik, S.; Mandal, D.; Ramanan, R., Oriented electric fields as future smart reagents in chemistry. Nat. Chem. 2016, 8, 1091-1098. (b) Shaik, S.; Ramanan, R.; Danovich, D.; Mandal, D., Structure and reactivity/selectivity control by oriented-external electric fields. Chem. Soc. Rev. 2018, 47 (14), 5125-5145. (c) Ciampi, S; Darwish, N.; Aitken, H. M.; Diez-Perez, I.; Coote, M. L. Harnessing Electrostatic Catalysis in single molecule, electrochemical and chemical sytems: a rapidly growing experimental tool box. Chem. Soc. Rev. 2018, 47 (14), 5146-5164.

[3] (a) Alemani, M.; Peters, M. V.; Hecht, S.; Rieder, K.-H.; Moresco, F.; Grill, L. Electric Field-Induced Isomerization of Azobenzene by STM $J$. Am. Chem. Soc. 2006, 128, 14446-14447. (b) Gorin, C. F.; Beh, E. S.; Kanan, M. W. An Electric Field-Induced Change in the Selectivity of a Metal Oxide-Catalyzed Epoxide Rearrangement. J. Am. Chem. Soc. 2012. 134 (1), 186-189. (c) Gorin, C. F.; Beh, E. S.; Bui, Q. M.; Dick, G. R.; Kanan, M. W., Interfacial Electric Field Effects on a Carbene Reaction Catalyzed by Rh Porphyrins. J. Am. Chem. Soc. 2013, 135 (30), 11257-11265. (d) Aragonès, A. C.; Haworth, N. L.; Darwish, N.; Ciampi, S.; Bloomfield, N. J.; Wallace, G. G.; Diez-Perez, I.; Coote, M. L., Electrostatic catalysis of a Diels-Alder reaction. Nature 2016, 531 (7592), 88-91. (e) Liu, M.; Pang, Y.; Zhang, B.; De Luna, P.; Voznyy, O.; Xu, J.; Zheng, X.; Dinh, C. T.; Fan, F.; Cao, C.; de Arquer, F. P. G.; Safaei, T. S.; Mepham, A.; Klinkova, A.; Kumacheva, E.; Filleter, T.; Sinton, D.; Kelley, S. O.; Sargent, E. H. Enhanced Electrocatalytic $\mathrm{CO}_{2}$ Reduction Via Field-Induced Reagent Concentration Nature 2016, 537, 382-386. (f) Zhang, L.; Laborda, E.; Darwish, N.; Noble, B. B.; Tyrell, J. H.; Pluczyk, S.; Le Brun, A. P.; Wallace, G. G.; Gonzalez, J.; Coote, M. L.; Ciampi, S. Electrochemical and Electrostatic Cleavage of Alkoxyamines J. Am. Chem. Soc. 2018, 140, 766-774. (g) Ryu, J.; Surendranath, $\mathrm{Y}$. Tracking Electrical Fields at the $\mathrm{Pt} / \mathrm{H}_{2} \mathrm{O}$ Interface during Hydrogen Catalysis. J. Am. Chem. Soc. 2019, 141 (39), 15524-15531. (h) Heo, J.; Ahn, H.; Won, J.; Gyeong Son, J.; Kyong Shon, H.; Geol Lee, T.; Woo Han, Sang; Baik, M.-H. Electro-inductive effect: Electrodes as functional groups with tunable electronic properties. Science 2020, 370 (6513), 214-219. (i) Shetty, M.; Ardagh, M. A.; Pang, Y.; Abdelrahman, O. A.; Dauenhauer, P. J. Electric-Field-Assisted Modulation of Surface Thermochemistry. ACS Catal., 2020, 10, 12867-12880. (j) Warburton, R. E.; Hutchison, P.; Jackson, M. N.; Pegis, M. L.; Surendranath, Y.; Hammes-Schiffer, S. "Interfacial Field-Driven Proton-Coupled Electron Transfer at Graphite-Conjugated Organic Acids" J. Am. Chem. Soc. 2020, in press.

[4] (a) DiRocco, D. A.; Noey, E. L.; Houk, K. N.; Rovis, T. Catalytic Asymmetric Intermolecular Stetter Reactions of Enolizable Aldehydes with Nitrostyrenes: Computational Study Provides Insight into the Success of the Catalyst. Angew Chem. Int. Ed. 201251 (10), 2391-2394. (b) Holland, M. C.; Paul, S. Schweizer, W. B.; Bergander, K.; Muck-Lichtenfeld, C.; Lakhdar, S.; Mayr, H.; Gilmour, R. Noncovalent Interactions in 
Organocatalysis: Modulating Conformation Diversity and Reactivity in the MacMillan Catalyst. Angew Chem. Int. Ed. 2013, 52 (31), 7967-7971. (c) Klinska, M.; Smith, L. M.; Gryn'ova, G.; Banwell, M. G.; Coote, M. L. Experimental Demonstration of $\mathrm{pH}$-dependent Electrostatic Catalysis of Radical Reactions. Chem. Sci. 2015, 10, 5623-5627. (d) Lee, K. L.; Silverio, D. L.; Torker, S.; Robbins, D. W.; Haeffner, F.; van der Mei, F. W.; Hoyeda, A. H. Catalytic Enantioselective Addition of Organoboron Reagents to Fluoroketones Controlled by Electrostatic Interactions. Nature Chem. 2016, 8, 768-777. (e) Kennedy, C. R.; Guidera, J. A.; Jacobsen, E. N. Synergistic Ion-Binding Catalysis Demonstrated via an Enantioselective, Catalytic [2,3]-Wittig Rearrangement. ACS Cent. Sci. 2016, 2 (6), 416-423. (f) Xiao, G.; Cintron-Rosado, G. A.; Glazier, D. A.; Xi, B-m.: Liu, C.; Lier, P.; Tang, W. Catalytic Site-Selective Acylation of Carbohydrates

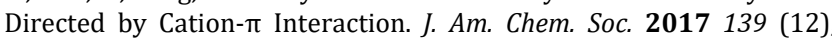
4246-4349. (g) Yamada, S. Cation-П Interactions in Organic Synthesis Chem. Rev. 2018, 118, 11353-11432. (h) Dhayalan, V.; Gadekar, S. C.; Alassad, Z.; Milo, A. Unravelling Mechanistic Features of Organocatalysis with in Situ Modifications at the Secondary Sphere Nature Chem. 2019, 11, 543-551.

[5] (a) Grajeda, J.; Kita, M. R.; Gregor, L. C.; White, P. S., Miller, A. J. M. Diverse Cation-Promoted Reactivity of Iridium Carbonyl Pincer-Crown Ether Complexes. Organometallics 2016, 35 (3), 306-316. (b) Reath, A H.; Ziller, J. W.; Tsay, C.; Ryan, A. J.; Yang, J. Y. Redox Potential and Electronic Structure Effects of Proximal Nonredox Active Cations in Cobalt Schiff Base Complexes Inorg. Chem. 2017, 56, 3713-3718. (c) Chattopadhyay, B.; Dannatt, J. E.; Andujar-DeSanctis, I. L.; Gore, K. A.; Maleckza Jr., R. E.; Singleton, D. A.; Smith III, M. R. Ir-Catalyzed ortho-Borylation of Phenols Directed by Substrate-Ligand Electrostatic Interactions: A Combined Experimental/in Silico Strategy for Optimizing Weak Interactions. J. Am. Chem. Soc. 2017, 139 (23), 7864-7871. (d) Lau, V. M.; Pfalzgraff, W. C.; Markland, T. E.; Kanan, M. W. Electrostatic Control of Regioselectivity in Au(I)-Catalyzed Hydroarylation. J. Am. Chem. Soc 2017, 139 (11), 4035-4041. (e) Chantarojsiri, T.; Ziller, J. W.; Yang, J. Y. Incorporation of redox-inactive cations promotes iron catalyzed aerobic C-H oxidation at mild potentials. Chem. Sci. 2018, 9, 2567-2574. (f) Dhar, D.; Yee, G. M.; Tolman, W. B., Effects of Charged Ligand Substituents on the Properties of the Formally Copper(III)-Hydroxide $\left([\mathrm{CuOH}]^{2+}\right)$ Unit. Inorg. Chem. 2018, 57 (16), 9794-9806. (g) Kang, K. Fuller, J.; Reath, A. H.; Ziller, J. W.; Alexandrova, A. N.; Yang, J. Y. Installation of Internal Electric Fields by Non-Redox Active Cations in Transition Metal Complexes Chem. Sci. 2019, 10, 10135-10142. (h) Erickson, J. D.; Preston, A. Z.; Linehan, J. C.; Wiedner, E. S. Enhanced Hydrogenation of Carbon Dioxide to Methanol by a Ruthenium Complex with a Charged Outer-Coordination Sphere. ACS Catal. 2020, 10 (13), 7419 7423. (i) Deacy, A. C.; Moreby, E.; Phanopoulos, A.; Williams, C. K Co(III)/Alkali-Metal(I) Heterodinuclear Catalysts for the Ring-Opening Copolymerizaiton of $\mathrm{CO}_{2}$ and Propylene Oxide. J. Am. Chem. Soc .2020 142(45), 19150-19160. (j) Oswald, V. F.; Lee, J. L.; Biswas, S.; Weitz, A C.; Mittra, K.; Fan, R.; Li, J.; Zhao, J.; Hu, M. Y.; Alp, E. E.; Bominaar, E. L. Guo, Y.; Green, M. T.; Hendrich, M. P.; Borovik, A. S., Effects of Noncovalent Interactions on High-Spin Fe(IV)-Oxido Complexes. J. Am. Chem. Soc. 2020, 142 (27) 11804-11817. (k) Martin, D. J.; Johnson, S. I.; Mercado, B. Q.; Raugei, S.; Mayer, J. M. Intramolecular Electrostatic Effects on $\mathrm{O}_{2}, \mathrm{CO}_{2}$, and Acetate Binding to a Cationic Iron Porphyrin. Inorg. Chem. 2020, in press.

[6] (a) Um, J. M.; DiRocco, D. A.; Noey, E. L.; Rovis, T.; Houk, K. N. Quantum Mechanical Investigation of the Effect of Catalyst Fluorination in the Intermolecular Asymmetric Stetter Reaction J. Am. Chem. Soc. 2011, 133, 11249-11254. (b) Lyngvi, E.; Bode, J. W.; Schoenebeck, F. A Computational Study of the Origin of Stereoinduction in Nhc-Catalyzed Annulation Reactions of A,B-Unsaturated Acyl Azoliums Chem. Sci. 2012 3, 2346-2350. (c) Yang, H.; Wong, M. W. Oxyanion Hole Stabilization by $\mathrm{C}-\mathrm{H} \cdots \mathrm{O}$ Interaction in a Transition State-a Three-Point Interaction Model for Cinchona Alkaloid-Catalyzed Asymmetric Methanolysis of Meso-Cyclic Anhydrides J. Am. Chem. Soc. 2013, 135, 5808-5818. (d) Nguyen, Q. N. N.; Lodewyk, M. W.; Bezer, S.; Gagné, M. R.; Waters, M. L.; Tantillo, D. J. Effects of Helix Macrodipole and Local Interactions on Catalysis of Acyl Transfer by A-Helical Peptides ACS Catalysis 2015, 5 , 1617-1622. (e) Seguin, T. J.; Wheeler, S. E. Electrostatic Basis for Enantioselective Brønsted-Acid-Catalyzed Asymmetric Ring Openings of Meso-Epoxides ACS Catalysis 2016, 6, 2681-2688. (f) Seguin, T. J.; Wheeler, S. E. Stacking and Electrostatic Interactions Drive the Stereoselectivity of Silylium-Ion Asymmetric Counteranion-Directed Catalysis. Angew Chem. Int. Ed. 201655 (51). 15889-15893. (g) Maji, R.;
Wheeler, S. E. Importance of Electrostatic Effects in the Stereoselectivity of NHC-Catalyzed Kinetic Resolutions. J. Am. Chem. Soc. 2017, 139 (36), 12441-12449. (h) Hill, N. S.; Coote, M. L. Strategies for Red-Shifting Type I Photoinitiators: Internal Electric Fields vs Lewis Acids vs Increasing Conjugation. Aust. J. Chem. 2019, 72, 627-632. (i) Blyth, M. T.; Coote, M. L., A pH-Switchable Electrostatic Catalyst for the Diels-Alder Reaction: Progress toward Synthetically Viable Electrostatic Catalysis $J$. Org. Chem. 2019, 84 (3), 1517-1522. (j) Blyth, M. T.; Noble, B. B.; Russell, I. C.; Coote, M. L. Oriented Internal Electrostatic Fields Cooperatively Promote Ground and Excited State Reactivity: A Case Study in Photochemical $\mathrm{CO}_{2}$ Capture, J. Am. Chem. Soc. 2020, 142 (29), 606-613. (k) Stuyver, T.; Ramanan, R.; Mallick, D.; Shaik, S., Oriented (Local) Electric Fields Drive the Millionfold Enhancement of the H-Abstraction Catalysis Observed for Synthetic Metalloenzyme Analogues. Angew. Chem., Int. Ed. 2020, 59 (20), 7915-7920. (l) Xu, L.; Izgorodina, E. I.; Coote, M. L. Ordered Solvents and Ionic Liquids Can be Harnessed for Electrostatic Catalysis, J. Am. Chem. Soc. 2020, 142, 12826-12833. (m) Doan, V.; Noble, B. B.; Coote, M. L. Electrostatic Activation of Tetrazoles, J. Org. Chem. 2020, 85 (15), 10091-10097.

[7] Joy, J.; Stuyver, T.; Shaik, S., Oriented External Electric Fields and Ionic Additives Elicit Catalysis and Mechanistic Crossover in Oxidative Addition Reactions. J. Am. Chem. Soc. 2020, 142 (8), 3836-3850.

[8] Hansch, C.; Leo, A.; Taft, R. W. A survey of Hammett substituent constants and resonance and field parameters. Chem. Rev. 1991, 91 (2), 165-195.

[9] (a) Ri, T.; Eyring, H. Calculation of Dipole Moments from Rates of Nitration of Substituted Benzenes and Its Significance for Organic Chemistry. J. Chem. Phys. 1940, 8 (6), 433. (b) Westheimer, F. H., The electrostatic effect of substituents on the dissociation constants of organic acids. IV. Aromatic acids. J. Am. Chem. Soc. 1939, 61 (8), 1977 1980.

[10] (a) Jaffe, H. H., Correlation of Hammett's $\sigma$ values with electron densities calculated by molecular-orbital theory.J. Chem. Phys. 1952, 20 (2), 279-84. (b) Jaffe, H. H., A reexamination of the Hammett equation. Chem. Rev.1953, 53 (2), 191-261.

[11] Burns, R. J.; Mati, I. K.; Muchowska, K. B.; Adam, C.; Cockroft, S. L. Quantifying Through-Space Substituent Effects. Angew. Chem. Int. Ed. 2020, 59 (38), 16717-16724.

[12] (a) Azcarate, I.; Costentin, C.; Robert, M.; Savéant, J.-M., ThroughSpace Charge Interaction Substituent Effects in Molecular Catalysis Leading to the Design of the Most Efficient Catalyst of $\mathrm{CO}_{2}$-to-CO Electrochemical Conversion. J. Am. Chem. Soc. 2016, 138 (51), 16639 16644. (b) Pegis, M. L.; Wise, C. F.; Koronkiewicz, B.; Mayer, J. M. Identifying and Breaking Scaling Relations in Molecular Catalysis of Electrochemical reactions. J. Am. Chem. Soc. 2017, 139 (32), 11000-11003. (c) Sung, S.; Kumar, D.; Gil-Sepulcre, M.; Nippe, M. Electrocatalytic $\mathrm{CO}_{2} \mathrm{Re}$ duction by Imidazolium-Functionalized Molecular Catalysts. J. Am. Chem. Soc. 2017, 139 (40), 13993-13996. (d) Yuan, Z.; Yang, H.; Malik N.; Čolović, M.; Weber, D. S.; Wilson, D.; Bénard, F.; Martin, R. E.; Warren, J. J.; Schaffer, P.; et al. Electrostatic Effects Accelerate DecatungstateCatalyzed C-H Fluorination Using $\left[{ }^{18} \mathrm{~F}\right]-$ and $\left[{ }^{19} \mathrm{~F}\right] \mathrm{NFSI}$ in Small Molecules and Peptide Mimics. ACS Catal. 2019, 9 (9), 8276-8284. (e) Sung, S.; Li, X.; Wolf, L. M.; Meeder, J. R.; Bhuvanesh, N. S.; Grice, K. A.; Panetier, J. A., Nippe, M. Synergistic Effects of Imidazolium-Functionalization on $\mathrm{fac} \mathrm{Mn}(\mathrm{CO})_{3}$ Bipyridine Catalyst Platforms for Electrocatalytic Carbon Dioxide Reduction. J. Am. Chem. Soc. 2019, 141 (16), 6569-6582. (f) Zhang, R.; Warren, J. J. Controlling the Oxygen Reduction Selectivity of Asymmetric Cobalt Porphyrins by Using Local Electrostatic Interactions. J. Am. Chem. Soc. 2020. 142 (31), 13426-13434. (g) Margarit, C. G.; Asimow, N. G.; Gonzalez, M. I.; Nocera, D. G. Double Hangman Iron Porphyrin and the Effect of Electrostatic Nonbonding Interactions on Carbon Dioxide Reduction. J. Phys. Chem. Lett. 2020, 11 (5), 1890-1895. [13] Tolman, C. A., Steric effects of phosphorus ligands in organometallic chemistry and homogeneous catalysis. Chem. Rev. 1977, 77 (3), 313-48

[14] (a) Hoic, D. A.; Davis, W. M.; Fu, G. C., Diphenylphosphidoboratabenzene: An Anionic Analogue of Triphenylphosphine. J. Am. Chem. Soc. 1996, 118 (34), 8176-8177. (b) Thomas, J. C.; Peters, J. C. Benzene C-H Activation at a Charge Neutral Zwitterionic Platinum(II) Complex. J. Am. Chem. Soc. 2001. 123 (21) 5100-5101. (c) Lu, C. C.; Peters, J. C. Catalytic Copolymerization of CO and Ethylene with a Charge Neutral Palladium (II) Zwitterion. J. Am Chem. Soc. 2002. 124 (19), 5272-5273. (d) Thomas, J. C.; Peters, J. C. Bis(phosphine)borates: A New Family of Monoanionic Chelating 
Phosphine Ligands. Inorg Chem 2003, 42 (17), 5055-5073. (e) Gott, A L.; Piers, W. E.; Dutton, J. L.; McDonald, R.; Parvez, M., Dimerization of Ethylene by Palladium Complexes Containing Bidentate Trifluoroborate-Functionalized Phosphine Ligands. Organometallics 2011, 30 (16), 4236-4249. (f) Kim, Y.; Jordan, R. F. Synthesis, Structures, and Ethylene Dimerization Reactivity of Palladium Alkyl Complexes That Contain a Chelating Phosphine-Trifluoroborate Ligand $O r$ ganometallics 2011, 30, 4250-4256. (g) Granville, S. L.; Welch, G. C.; Stephan, D. W. Ni, Pd, Pt, and Ru Complexes of Phosphine-Borate Ligands. Inorg. Chem. 2012. 51 (8), 4711-4721. (h) Alcarazo, M., $\alpha$-Cationic Phosphines: Synthesis and Applications. Chem. Eur. J. 2014, 20 (26), 7868-7877. (i) Tassone, J. P.; Mawhinney, R. C.; Spivak, G. J. An Examination of the Effects of Borate Group Proximity on Phosphine Donor Power in Anionic (Phosphino)tetraphenylborate Ligands. J. Organomet. Chem. 2015, 776, 153- 156. (j) Chan, A. L.; Estrada, J.; Kefalidis, C. E.; Lavallo, V., Changing the Charge: Electrostatic Effects in Pd-Catalyzed Cross-Coupling. Organometallics 2016, 35 (19), 3257-3260. (k) Dai, Y.; He, S.; Peng, B.; Crandall, L. A.; Schrage, B. R.; Ziegler, Z. J.; Jia, L. Zwitterionic Design Principle of Nickel(II) Catalysts for Carbonylative Polymerization of Cyclic Ethers. Angew. Chem. Int. Ed. 2018. 57 (43), 14111-14115. (l) Fischer, P. J.; Senthil, S.; Stephan, J. T.; Swift, M. L.; Storlie, M. D.; Chan, E. T.; Vollmer, M. V.; Young Jr., V. G. Inductive Modulation of tris(phosphinemethyl)phenylborate donation at group $\mathrm{VI}$ metals via borate phenyl substituent modification. Dalton Trans. 2018, 17, 6166-6176. (m) Konishi, S.; Iwai, T; Sawamura, M., Synthesis, properties, and catalytic application of a triptycene-type borate-phosphine ligand. Organometallics 2018, 37 (12), 1876. (n) Drover, M. W.; Nagata, K.; Peters, J. C. Fusing Triphenylphosphine with Tetraphenylborate: Introducing the 9-Phosphatriptycene-10-Phenylborate (Ptb) Anion Chem. Comm. 2018, 54, 7916-7919.

[15] Oliviera, R. A.; Silva, R. O.; Molander, G. A.; Menezes, P. H. ${ }^{1} \mathrm{H}^{13} \mathrm{C}{ }^{19} \mathrm{~F}$ and ${ }^{11} \mathrm{~B}$ NMR spectral reference data of some potassium organotrifluoroborates. Mag. Resonance. Chem. 2009, 47 (10), 873-878.

[16] Chen, L.; Ren, P.; Carrow, B. P., Tri(1-adamantyl)phosphine: Expanding the Boundary of Electron-Releasing Character Available to Organophosphorus Compounds. J. Am. Chem. Soc. 2016, 138 (20), 6392 6395.

[17] (a) Allen, D. W.; Taylor, B. F. The chemistry of heteroarylphosphorus compounds. Part 15. Phosphorus-31 nuclear magnetic resonance studies of the donor properties of heteroarylphosphines towards selenium and platinum(II). J. Chem. Soc., Dalton Trans. 1982, 51-54. (b) Niemayer, Z. L.; Milo, A.; Hickey, D. P.; Sigman, M. S. Parametrization of Phosphine Ligands Reveals Mechanistic Pathways and Predicts Reaction Outcomes. Nat. Chem. 2016. 8 (6), 610-617.

[18] Anslyn, E. V.; Dougherty, D. A. Modern Physical Organic Chemistry. $5^{\text {th }}$ Ed, University Science, Herndon, VA, 2005.

[19] (a) Carr, S. W.; Colton, R. Hydrogen-1, Carbon-13, Phosphorus-31 and Selenium-77 N.M.R. Studies on Organophosphorus Selenides, Aust J. Chem. 1981 , 34 , 35-44. (b) Hrib C. G.; Ruthe F.; Seppälä, E.; Bätcher, M.; Druckenbrodt, C.; Wismach, C.; Jones, P. G.; du Mont, W.; Lippolis, V.; Devillanova, F. A.; Bühl, M. The Bromination of Bulky Trialkylphosphane Selenides R2R'PSe (R, R' = iPr or tBu) Studied by Physical and Computational Methods. Eur. J. Inorg. Chem. 2006, 88-100.

[20] Wang, P. Anderko, A. Computation of dielectric constants of solvent mixtures and electrolyte solutions. Fluid Phase Equilibr. 2001, 186 (1-2), 103-122
[21] Grevels, F.-W.; Jacke, J.; Klotzbücher, W. E.; Krüger, C.; Seevogel, K. Tsay, Y.-H. Dynamic Processes on the IR Time Scale: Coalescence of CO Stretching Vibrational Bands in $\left[\left(\mathrm{H}_{4}\right.\right.$-diene $\left.) \mathrm{Fe}(\mathrm{CO})_{3}\right]$ Complexes Angew. Chem. Int. Ed. 1987, 26, 885-887.

[22] Cronin, L.; Higgitt, C. L.; Karch, R.; Perutz, R. N. Rapid Intermolecular Carbon-Fluorine Bond Activation of Pentafluoropyridine at Nickel(0): Comparative Reactivity of Fluorinated Arene and Fluorinated Pyridine Derivatives. Organometallics 1997, 16 (22), 4920-4928. [23] J-W.; Wang, L-N.; Li, M.; Tang, P-T.; Luo, X-P.; Jurmoo, M.; Liu, Y-J.; Zeng, M-H. Ruthenium-Catalyzed Gram-Scale Preferential C-H Arylation of Tertiary Phosphine. Org. Lett. 2019, 21 (8), 2885-2889.

[24] Molander, G. A.; Ham, J. Synthesis of Functionalized Organotrifluoroborates via Halomethyltrifluoroborates. Org. Lett. 2006. 8 (10), 2031-2034

[25] Sheldrick, G. M. SHELXT- Integrated space-group and crystalstructure determination. Acta Cryst. 2015, A71, 3- 9.

[26] Dolomanov, O.V.; Bourhis, L. J.; Gildea, R. J.; Howard, A. K.; and Puschmann, H.,. Olex2, a complete structure solution, refinement, and analysis program. J. Appl. Cryst. 2009. 42, 339

[27] (a) Sheldrick, G. M. A Short History of SHELX. Acta Cryst. 2008, A64, 112-122. (b) Sheldrick, G. M. Crystal structure refinement with SHELX. Acta Cryst. 2015, C71, 3-8.

[28] (a) Diaz, A. A.; Buster, B.; Schomish, D.; Khan, M. A.; Baum, C. J.; Wehmschulte, R. J. Size Mattters: Room Temperature P-C Bond Formation Through C-F Activation in $m$-Terphenyldiiodophosphine. Inorg. Chem, 2008, 47 (7), 2858-2863. (b) Kreienbrink, A.; Sarosi, M. B.; Rys, E. G.; Lonnecke, P.; Hey-Hawkins, E. Carborane-substituted 1,2-Diphosphetanes. Angew. Chem. Int.Ed., 2011, 50 (20), 4701-4703.

[29] Neese, F. The ORCA program system. Wiley interdisciplinary Reviews - Computational Molecular Science, 2012, 2 (1), 73-78.

[30] Gaussian 16, Revision B.01, Frisch, M. J.; Trucks, G. W.; Schlegel, H. B.; Scuseria, G. E.; Robb, M. A.; Cheeseman, J. R.; Scalmani, G.; Barone, V.; Petersson, G. A.; Nakatsuji, H.; Li, X.; Caricato, M.; Marenich, A. V.; Bloino, J.; Janesko, B. G.; Gomperts, R.; Mennucci, B.; Hratchian, H. P.; Ortiz, J. V.; Izmaylov, A. F.; Sonnenberg, J. L.; Williams-Young, D.; Ding, F.; Lipparini, F.; Egidi, F.; Goings, J.; Peng, B.; Petrone, A.; Henderson, T.; Ranasinghe, D.; Zakrzewski, V. G.; Gao, J.; Rega, N.; Zheng, G.; Liang, W.; Hada, M.; Ehara, M.; Toyota, K.; Fukuda, R.; Hasegawa, J.; Ishida, M.; Nakajima, T.; Honda, Y.; Kitao, O.; Nakai, H.; Vreven, T.; Throssell, K.; Montgomery, J. A., Jr.; Peralta, J. E.; Ogliaro, F.; Bearpark, M. J.; Heyd, J. J.; Brothers, E. N.; Kudin, K. N.; Staroverov, V. N.; Keith, T. A.; Kobayashi, R.; Normand, J.; Raghavachari, K.; Rendell, A. P.; Burant, J. C.; Iyengar, S. S.; Tomasi, J.; Cossi, M.; Millam, J. M.; Klene, M.; Adamo, C.; Cammi, R.; Ochterski, J. W.; Martin, R. L.; Morokuma, K.; Farkas, O.; Foresman, J. B.; Fox, D. J. Gaussian, Inc., Wallingford CT, 2016.

[31] Struppe, J.; Zhang, Y.; Rozovsky, S. ${ }^{77}$ Se Chemical Shift Tensor of Lselenocystine: Experimental NMR Measurements and Quantum Chemical Investigations of Structural Effects. J. Phys. Chem. B. 2015, 119 (9), 3643-3650. 

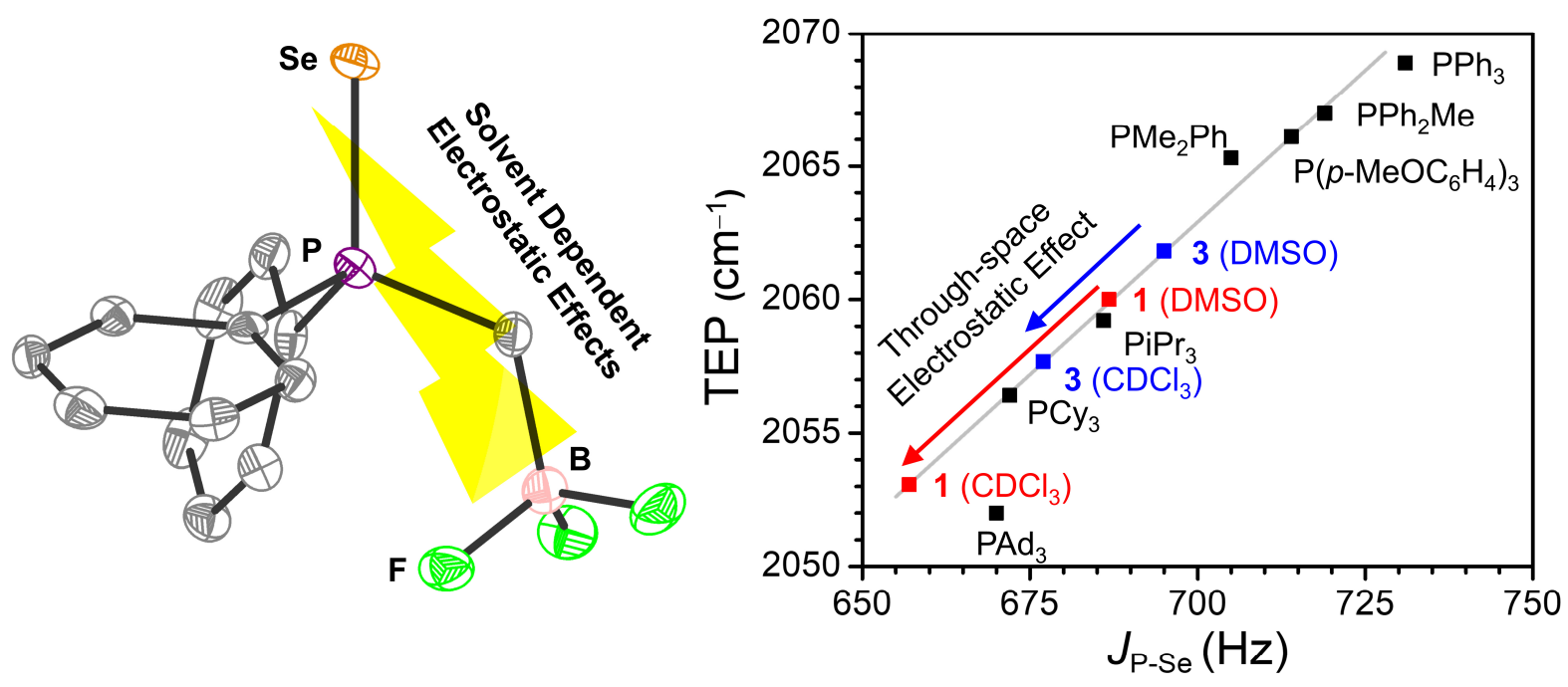